\title{
دور القيم التربوية في رعاية الأطفال ذوي الاحتياجات التزبوية الخاصة ومواجهة ظاهرة الإساية والاهمال في ضوي الاتجاهات التزبوية المعاصرة
}

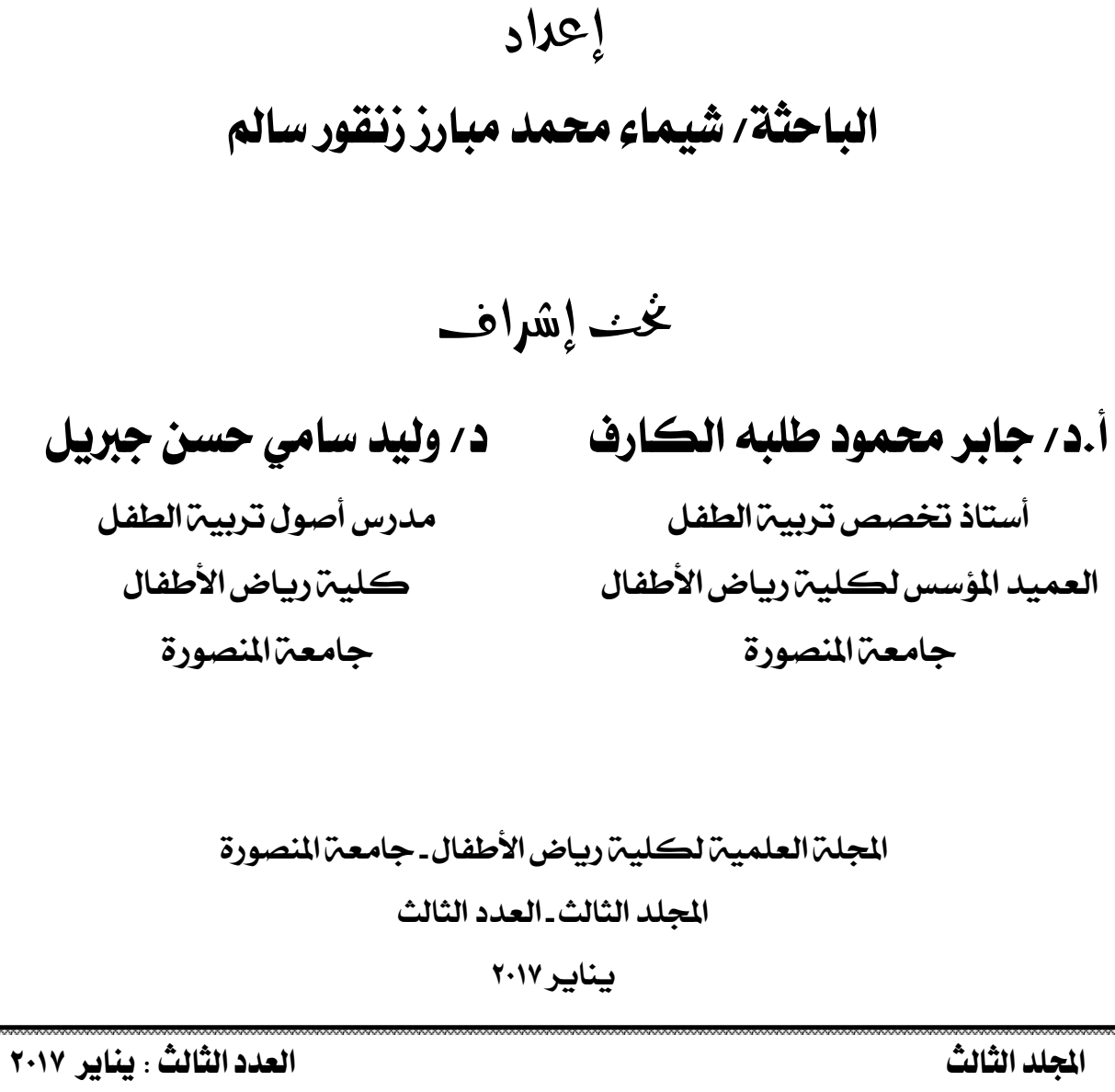

د د وليد سامي حسن جبريل

مدرس أصول تربيت الطفل كليتترياض الأطفال

جامعت المنصورة

المجلت العلميت لكليت رياض الأطفال ـ جامعت المنصورة

المجلد الثالث_ العدد الثالث

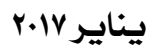

أ.د/ جابر محمود طلبه الكارف

أستاذ تخصص تربيت الطفل

العميد المؤسس لكليتترياض الأطفال

جامعت المنصورة 


\section{دور القيم التزبوية في رعاية الأطفال ذوي الاحتياجات التزبوية الخاصة ومواجهة ظاهرة الإسائة والاهمال في ضوي الاتجاهات التزبوية المعاصرة}

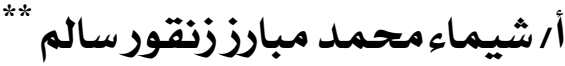

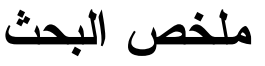

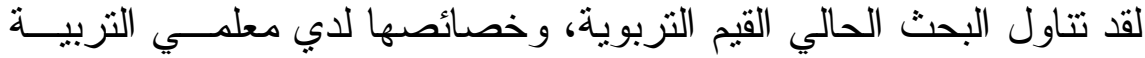

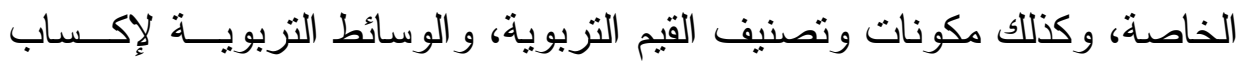

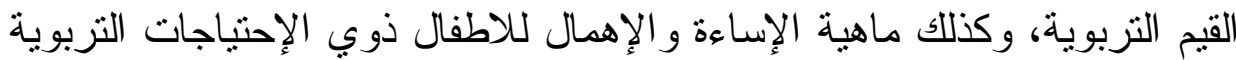

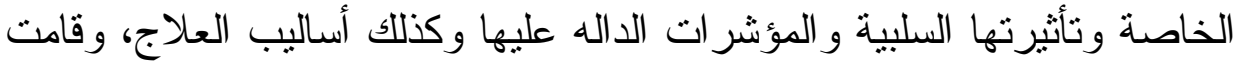

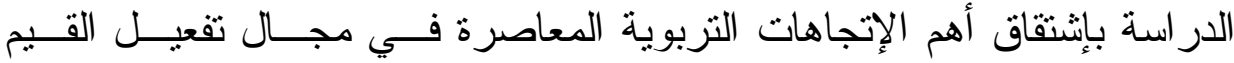

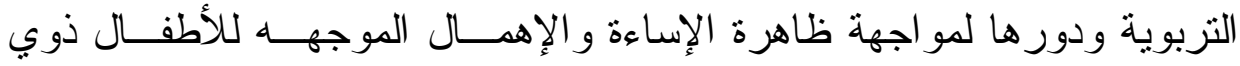

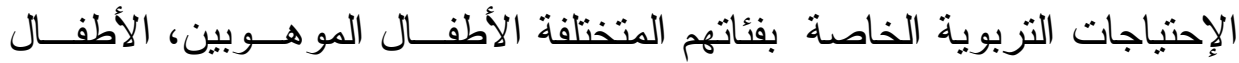
المعاقين إعاقات تقليدية وركز البحث محور إهتمامه علي الأطفال المعاقية الإنين عقلياً

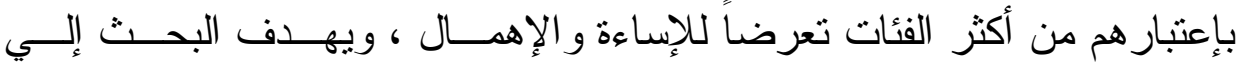

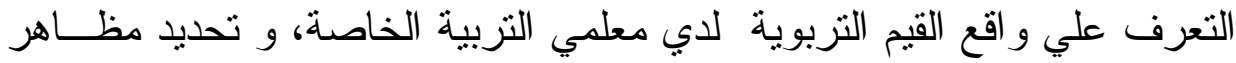

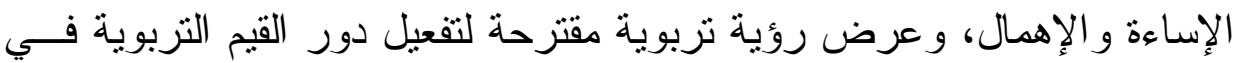

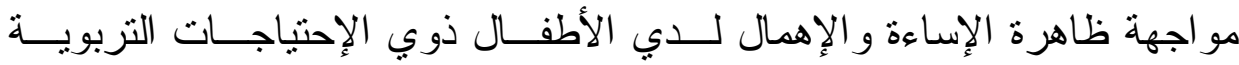
الخاصة في ضوء الإتجاهات التربوية المعاصرة.

الكلمات المفتاحية القيم التربوية - الأطفال ذوي الاحتياجات التربوية الخاصــة - الاســــاءة و الاهمال.

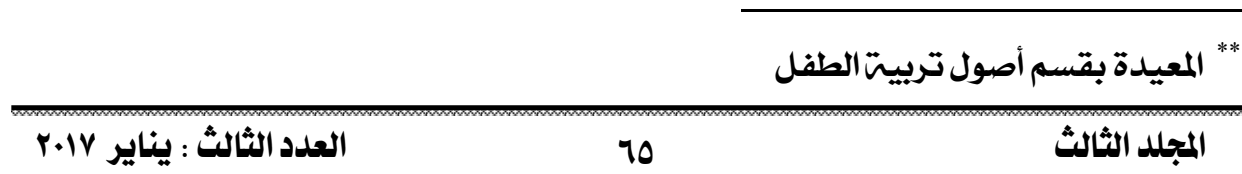




\section{دور القيم التزبوية في رعاية الأطفال ذوي الاحتياجات التزبوية الخاصة ومواجهة ظاهرة الإسائة والاهمال في ضوي الاتجاهات التربوية المعاصرة}

أر شيماء محمد مبارززنقور سالم**

\section{مقمة}

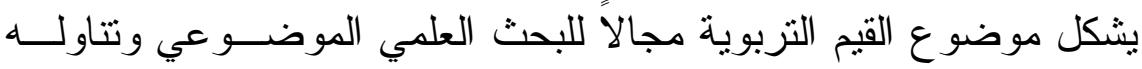

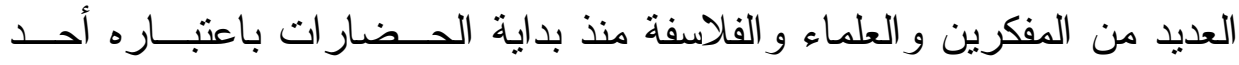

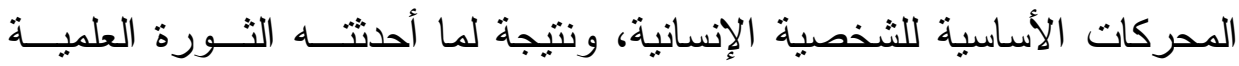

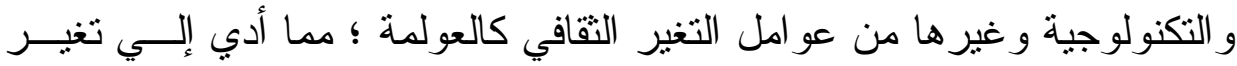

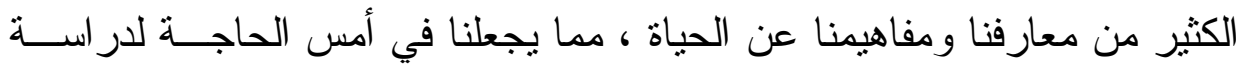

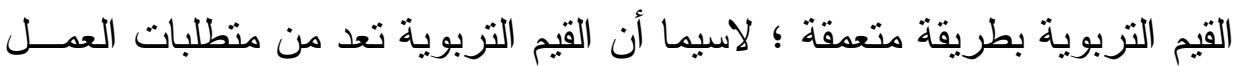

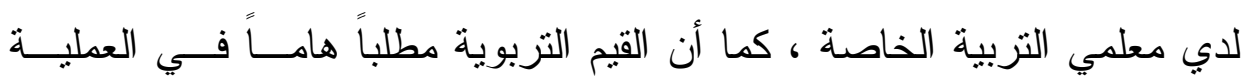

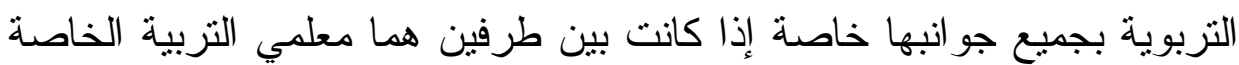
و الأطفال ذوي الاحتياجات التزبوية الخاصة.

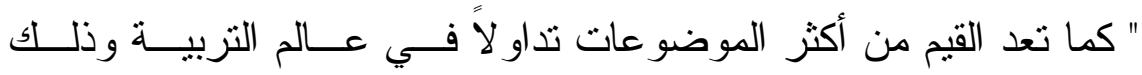

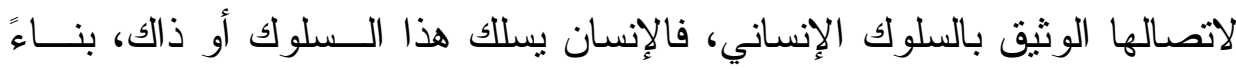

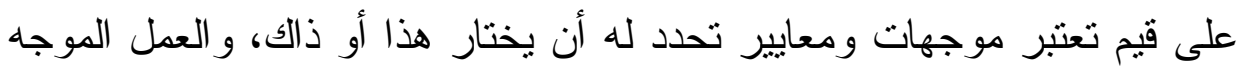

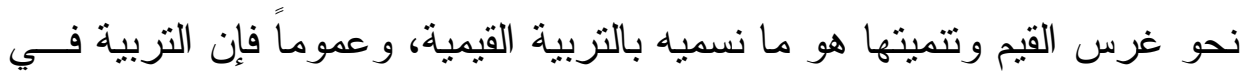

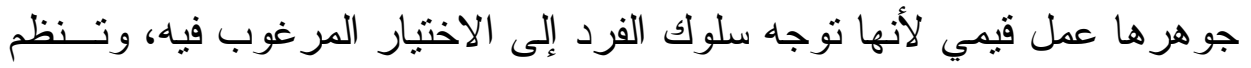

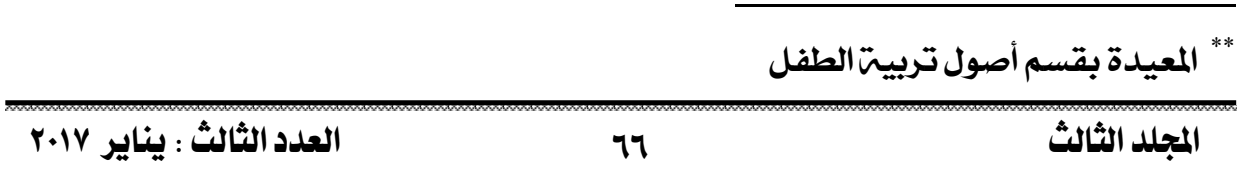


علاقاته بالآخرين، فالقيم و التزبية وجهان لعملة واحدة فبـــون القـيم لا تكـــن

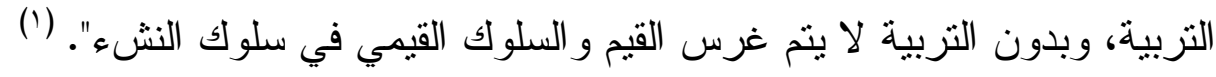

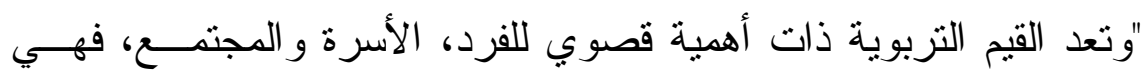

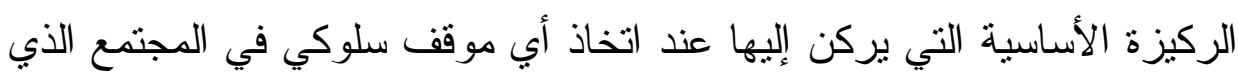

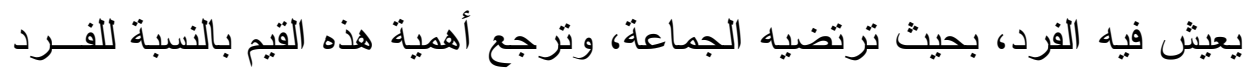

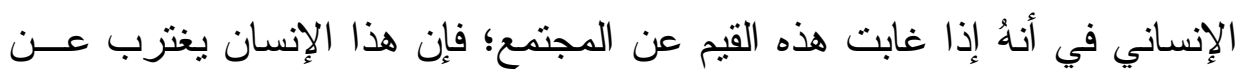

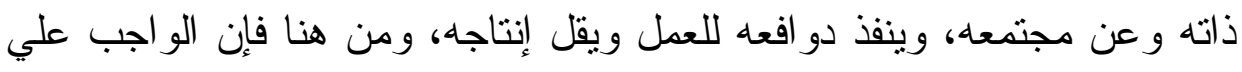

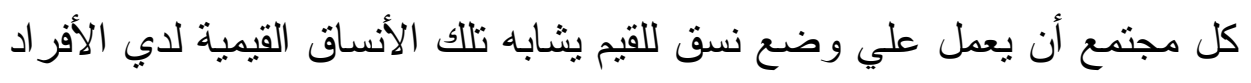

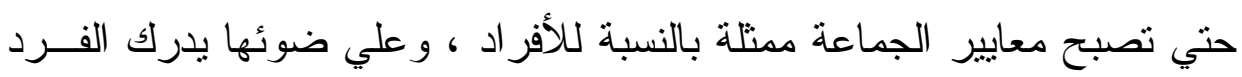

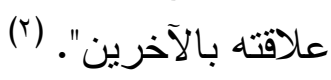
" كما تعد القيم التربوية أحد مرنكزات العمل التربوي، بل هي أهم أهدافه،

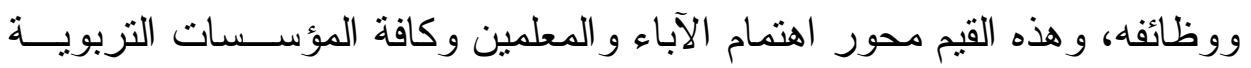

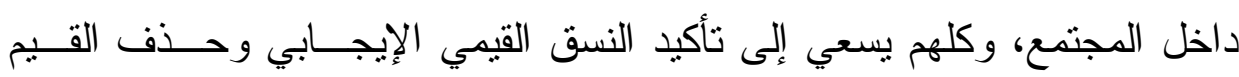

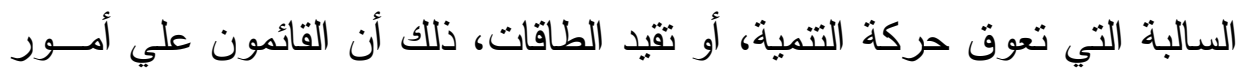

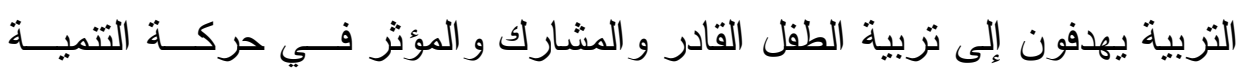

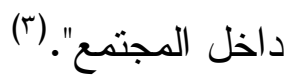

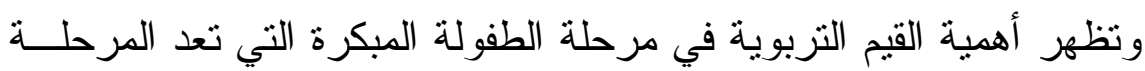

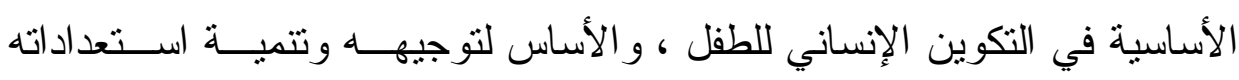

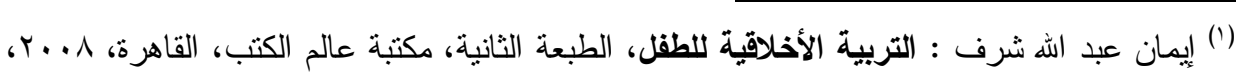

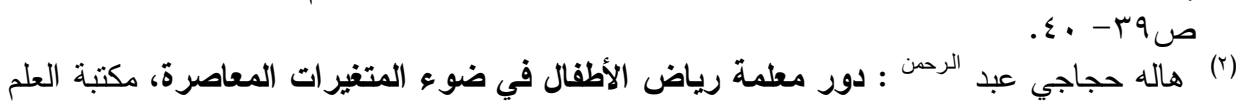

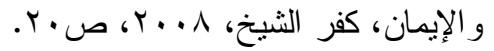
(r) حسن السيد شحاتة: أدب الطفل العربي دراسات وبحوث، الطبعة الثانية، الدار الصصرية اللبنانيـة،

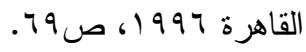


ووضع أسس التربية الاجتماعية و الخلقية السليمة ، وإيقـاظ العــلـ الإيجـابي

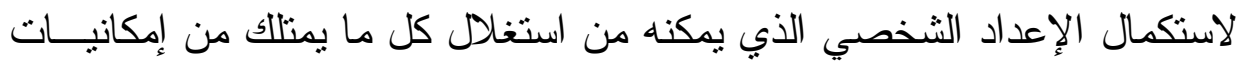

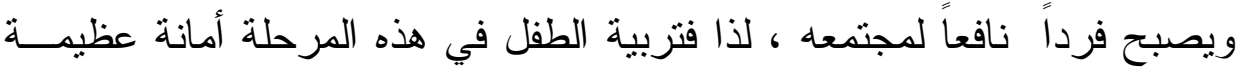
ومسئولية جسيمة سوف يسأل عنها كل من يحملها من مشرفات رياض الأطفال،

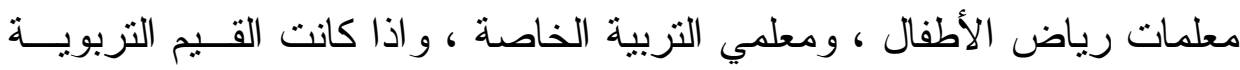

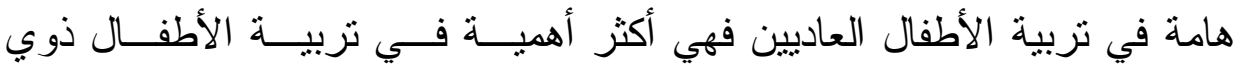

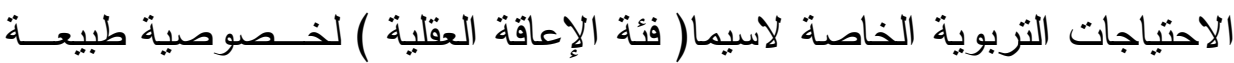

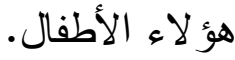

" فالقيم هي التي تعطي لحياة الأطفال معني وغرضــاً، فتوافـق أطفــال

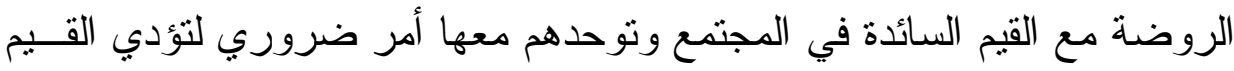

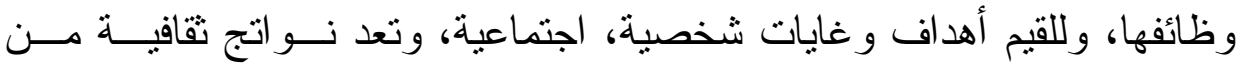

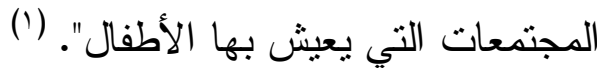
" وتتادي بعض الاتجاهات العالمية بالتمسك بالقيم التربوية ، ففي المدارس

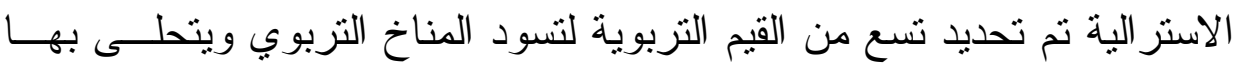

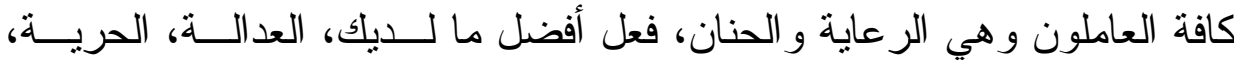

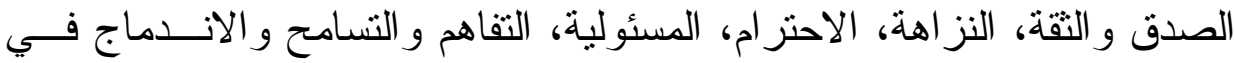

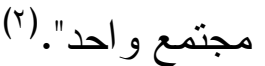

(1) محمد السيد حالوة: الأدب القصصي للطفل مضمون اجتماعي نفسي، هؤسسة حسورس الدوليـة،

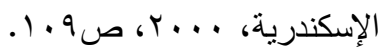

(3) Commonwealth of Australian, department of education, science and training, National Frame Work for Values Education in Australian Schools 2005, p36. 
فإذا غاب عن عقول بعض الأفر اد الجهلاء في أبي مجتمع من المجتمعات

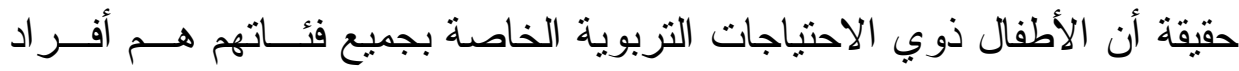

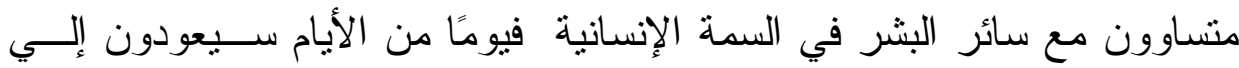

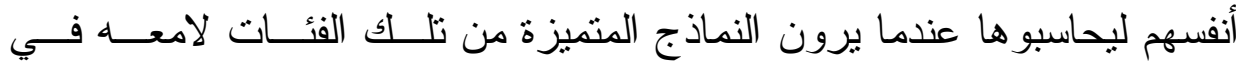

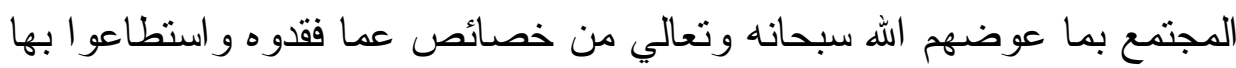

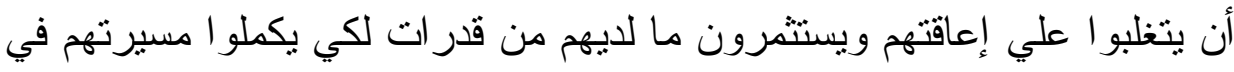

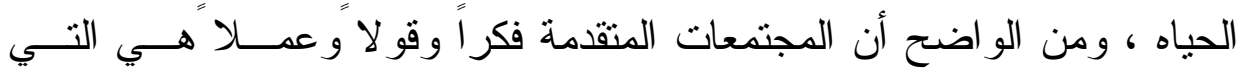
تحتوي هؤ لاء الأطفال وتهتم بهم وتحاول جاهده مو اجهة الإساءة المقدمة إليهم. وللأسف الثديد، فإن ظاهرة الإساءة والإهمال للأطفال ذوي الاحتياجـات

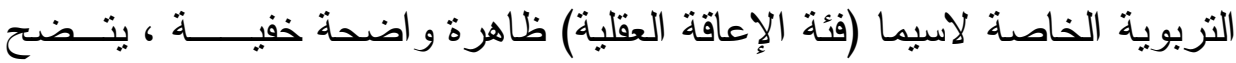

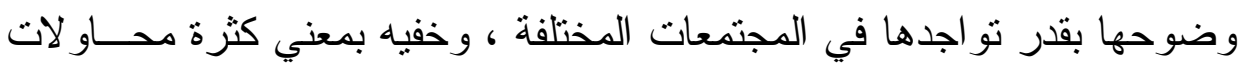

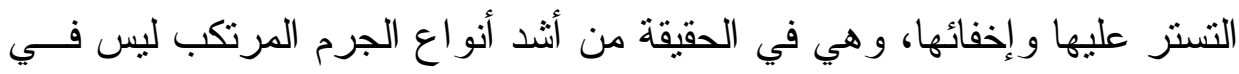

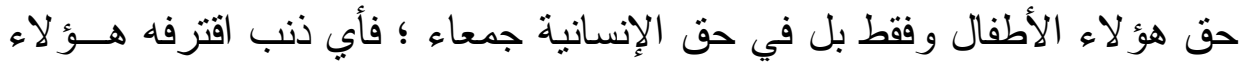

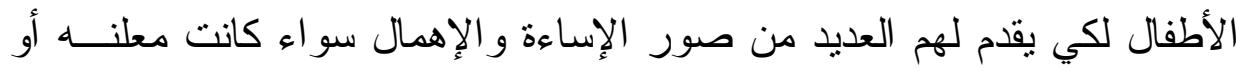

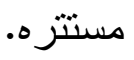

فالإساءة و الإهمال توجه للعديد مــن فئسات الأطفــال ذوي الاحتياجــات

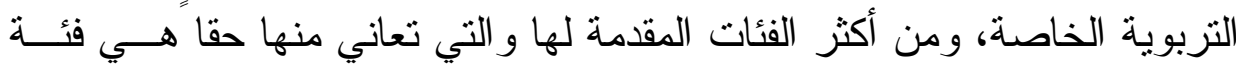

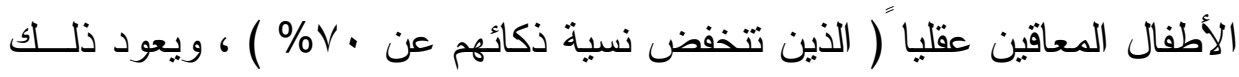

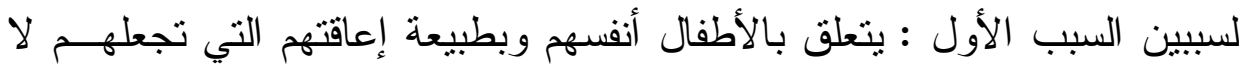

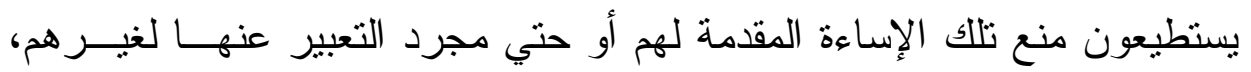

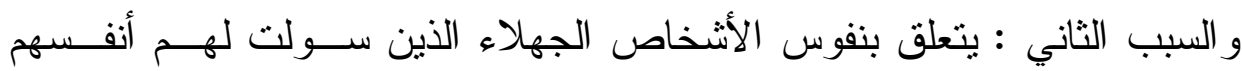

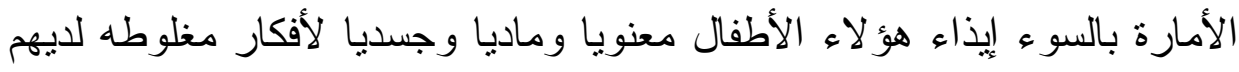

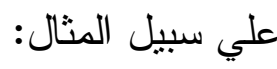


ـ الأطفال المعاقين عقليا عاله على المجتمع لا فائدة منهم. - الأطفال المعاقين عقليا في مستوي أدني من الأطفال العاديين. - الأطفال المعاقين عقليا أثخاص يثيرون الانفعال ويستحقو العقاب.

ليس هذا فحسب، ولكن الأطفال الملائكيين قد اختصهم الله سبحانه وتعالي

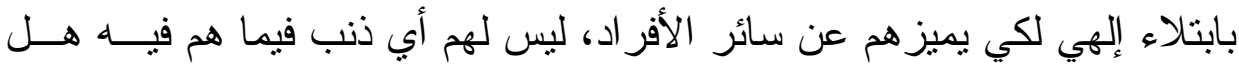

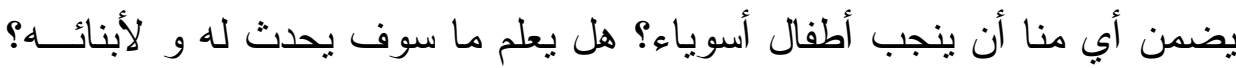

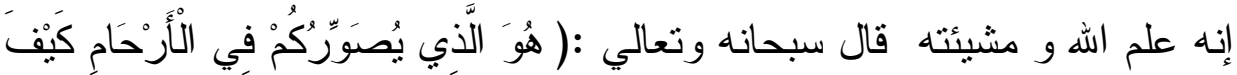

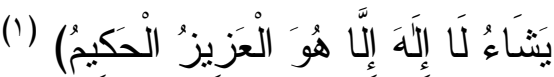

" كما أوضحت إحصائية اللجنة القومية لوقاية الطفل المساء معاملته عــامٍ

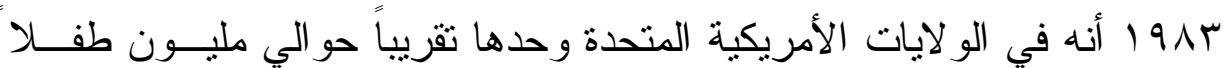

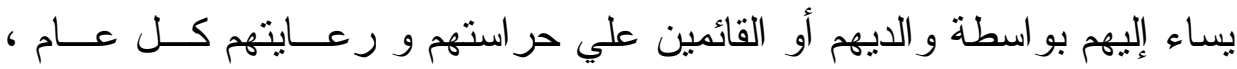

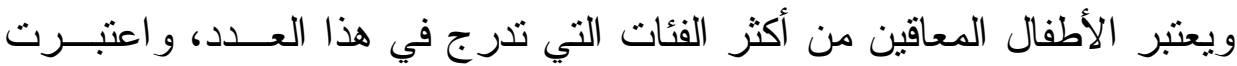
اللجنة القومية هذه التقدير ات مشكلة صحية قومية عظي يجب التصني التصدي إليها".(؟) " فالإعاقة - كابتلاء - تمثل أقدار إلهية قد كتبت في اللوح الدحفوظ فــي

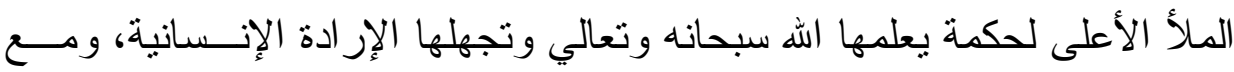
ذللك فهي قابلة للطف فيما جرت به الدقادير ، بالصبر الجميل ودفع الـبلاء قـــر المستطاع، و إخلاص الدعاء بالتضر ع إلي المولي الكريم لكثف الضر بمــنيئة

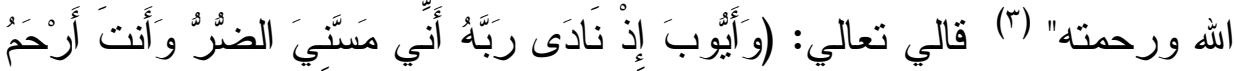

$$
\text { (1) القرآن الكريم: سورة آل عمر ان/ إلآية } 7 .
$$

(") (لههي أحمد أمين: المتظفلفون عقلياً بين الإساءة والإهمال، دار قباء للنشر و التوزيع ، القـاهرة ،

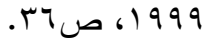

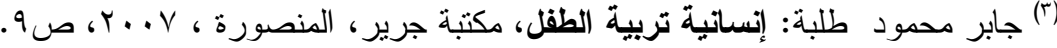




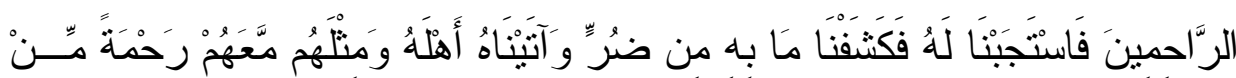

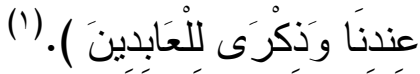

" و على الرغم مما سبق توضحيه، فإن ميلاد أو اكتثاف طفل معاق فـي الإني

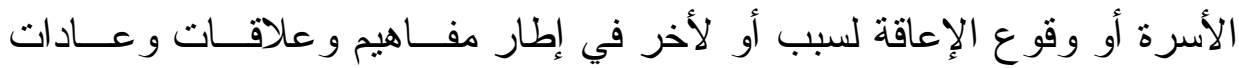

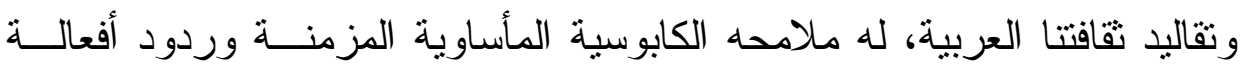

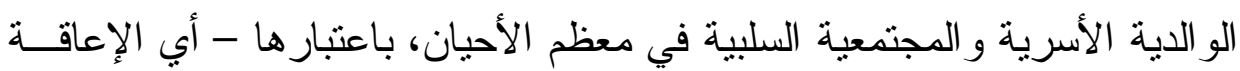

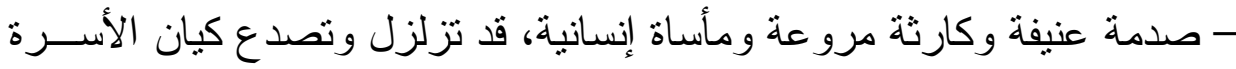

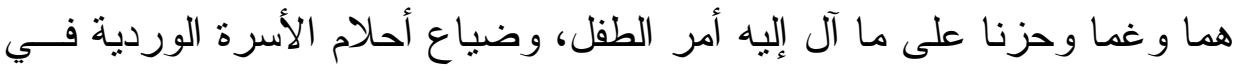

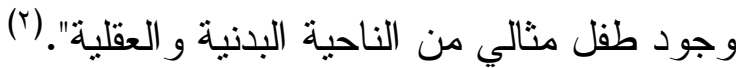

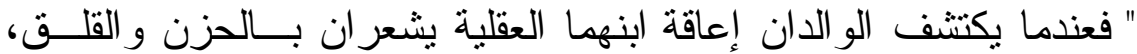
حيث أن الإعاقة تجعل الطفل غير قادر علي أن يمارس حياته ودوره في الأسرة

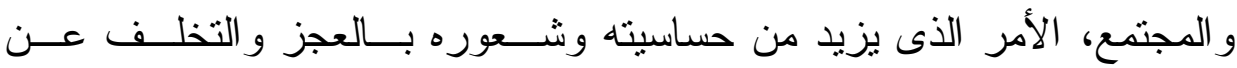

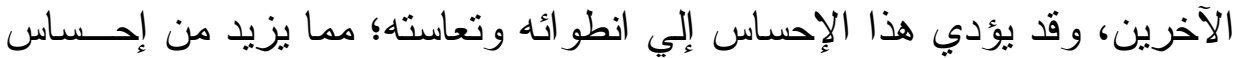

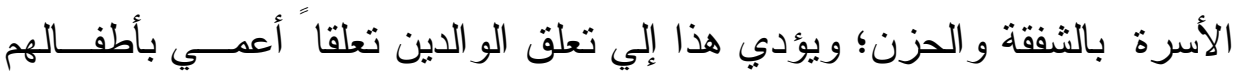

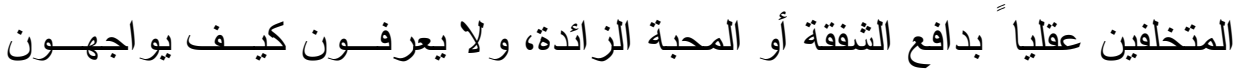

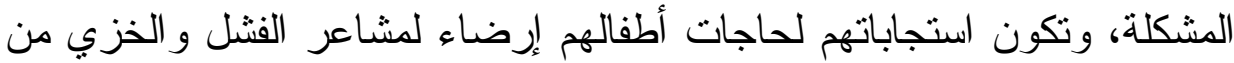

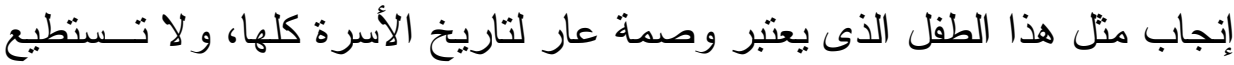

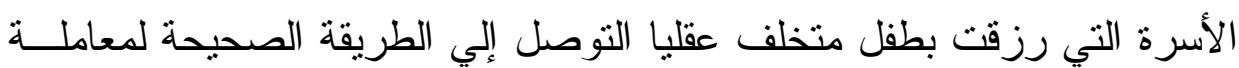

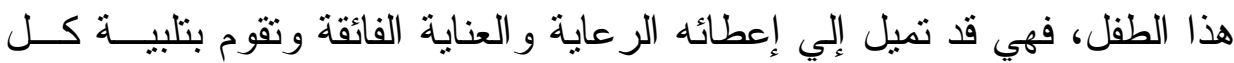

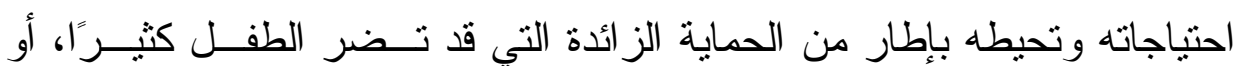

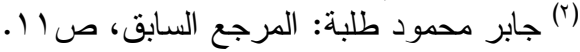


تواجه الأمر بحساسية شديدة وقلق وحرج اجتماعي حيث تمتتع الأسرة عن بناء

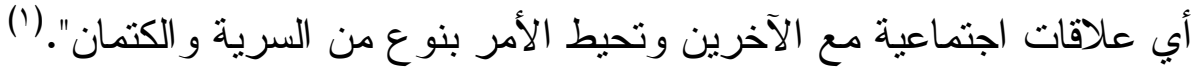
وليس هذا وحسب، ولكن إذا كانت الإساءة و الإهمال للأطفــال العــاديين

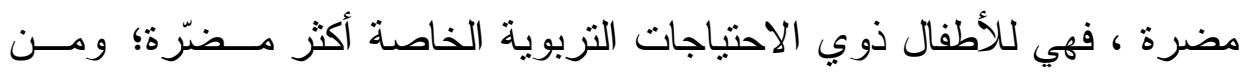

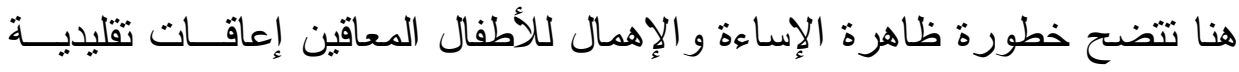

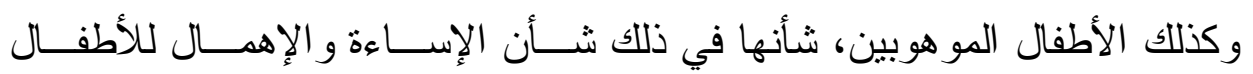

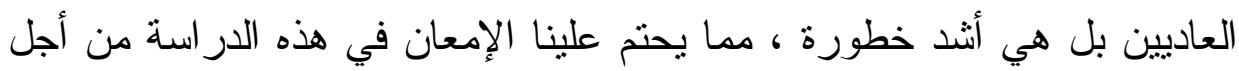

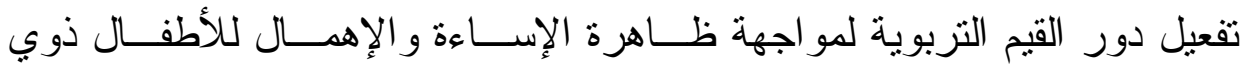

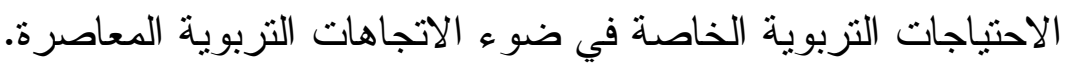

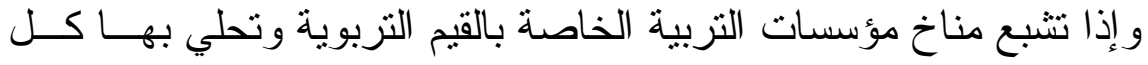

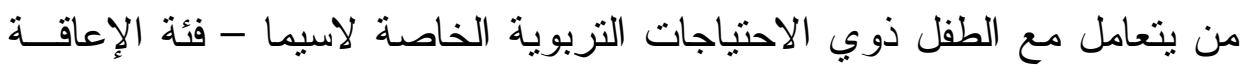

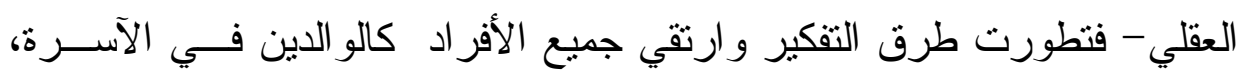

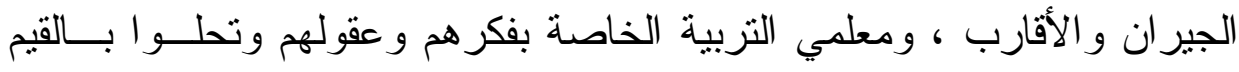
الثربوية و الأخلاقية السامية سوف يتخير الكثير من الرؤي تجاه هؤ لاء الأطفــال،

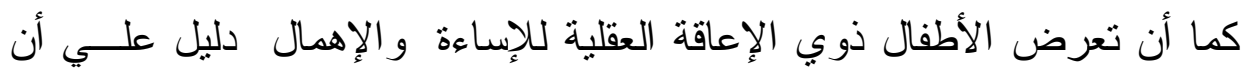

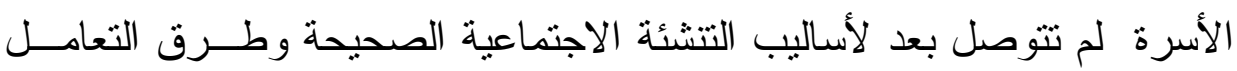

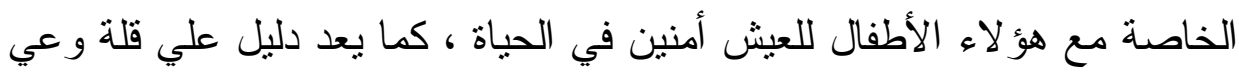

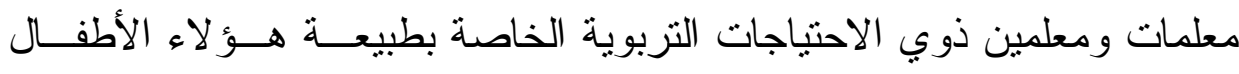

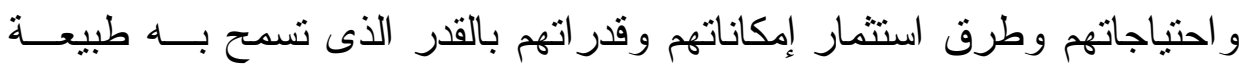

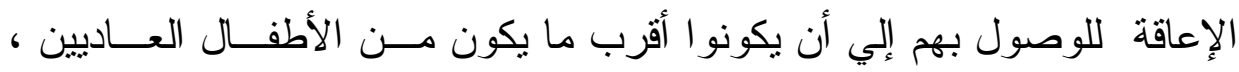

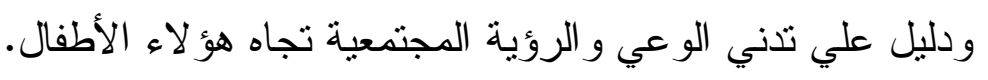
(1) إيمان فؤاد الكاثف: الإعاقة العقلية بين الإهمال والتوجيه، مكتبة الفجالة، القاهرة ، ( . ب ، ص 
الار اسة الاستطلاعية

قامت الباحثــة بدر اســـة اســنطلاعية فـي بعـض مـــارس الأطفــال ذوي الاحنياجات التربوية الخاصة ( لاسيما التربية الفكرية بالمنصورة ) علـي

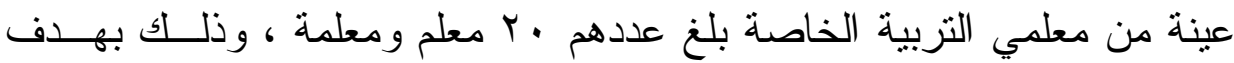
الوقوف على بعض المؤشرات التي تخص موضوع الدر اسة ويمكن حصرها في الاتي: - 20 - n

1. الوقوف على و اقع التعامل مع الأطفال ذوى الاحتياجات التربوية الخاصة في مؤسسات رعايتهم لاسيما الحكومية منها. r. توضيح ددي نوفر القيم التربوية لدي معلمي الأطفال ذوى الاحتباجـات التزبوية الخاصة. r. توضيح مدي إسهام القيم التربوية لدي معلمي الأطفال ذوى الاحتياجــات الخاصة في مو اجهة ظاهرة الإساءة و الإهمال. وقد توصلت الباحثة من الدراسة الاستطلاعية إلي:

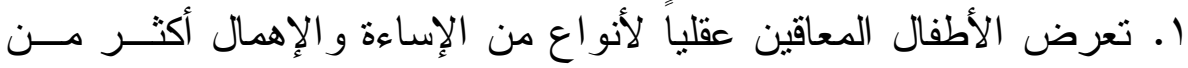
الأطفال ذوي الإعاقات الأخرى (كالمكفوفين، الصم و البكم). r. تدني مستوي تطبيق القيم التربوية لدي بعض معلمي التربية الخاصة مما

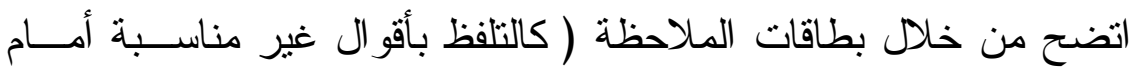
الأطفال وللأطفال، قضاء وقت العمل في الحديث عن الأعمال المنزليــة

$$
\text { و إهدار الوقت المتعدد). }
$$

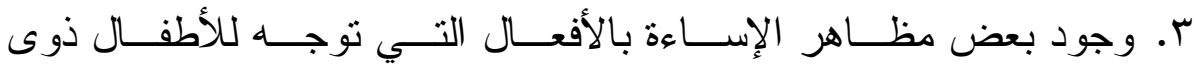

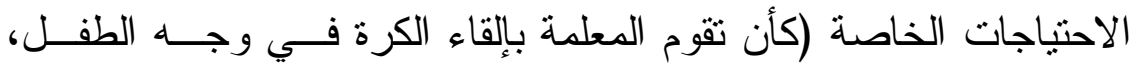

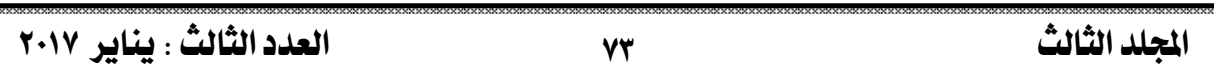


وجذب الأثنياء منه بعنف، وضربه حينما يلمس جهاز المحمول الخــاص

ع. وجود بعض جو انب الإهمال من حيث ترك مواجهــة إثنـباع حاجــات

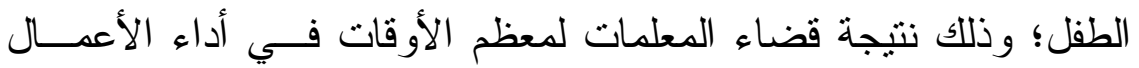

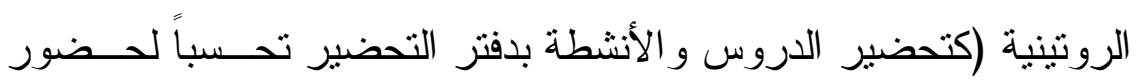

$$
\text { مشرف الروضة أو المدرسة). }
$$

ومن أهم الصعوبات التي واجهت الباحثة أثناء الدراسة الاستطلاعية ه قلة عدد الأطفال ذوي الاحتباجات التزبوية الخاصة، وفي بعض الأحبان لا يتو اجد الأطفال نهائيا ينفي وجود مبرر لبقاء الباحثة داخل المؤسسة. • انشغال معلمي التربية الخاصة بأمور روتينية تقلل تفاعلهم مع الأطفــال وبالتالي تصعب ملاحظة تصرفات المعلمات إز اء الأطفال. بعض الاراسات السابقة في مجال البحث

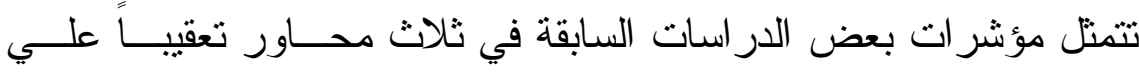

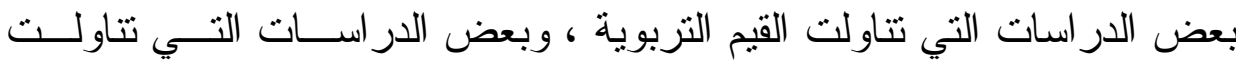

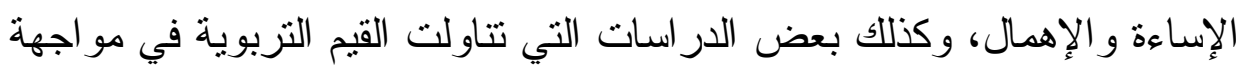

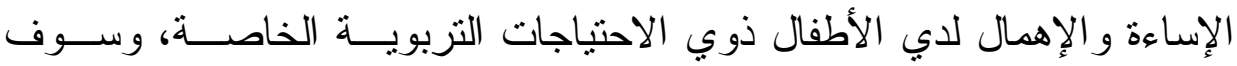

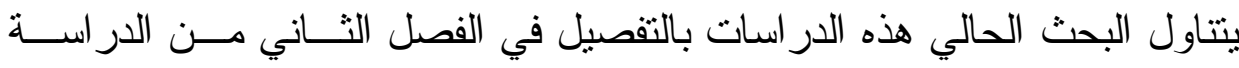

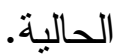

يتضح من بعض الدراسات السابقة التي تتاولت القيم التزبوية لاي معلمي

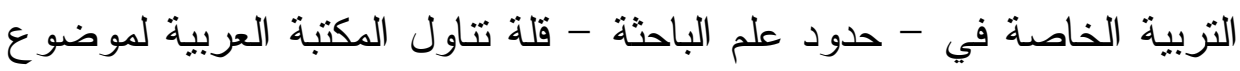

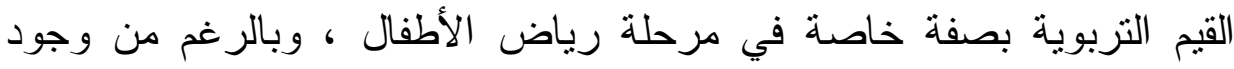


بعض الدر اسات القليلة التي حاولت إلقاء الضوء علي القيم التربوية لدي طفل ما

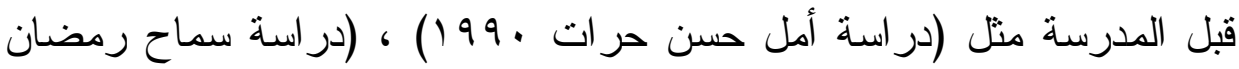

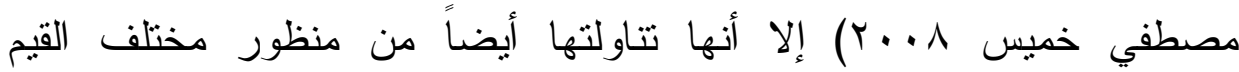

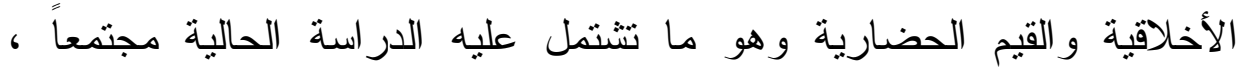
وبعض الدراسات ركزت علي القيم الأخلاقية الحضارية لدي تلاميذ مرحلة

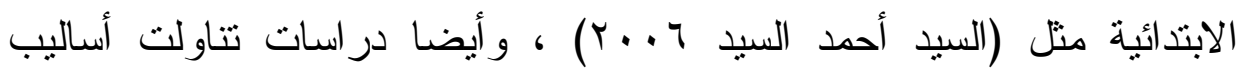
الرسول صلي الله علية وسلم في تربية الأطفال لمو اجهة تحديات العصر مثل الكاتل

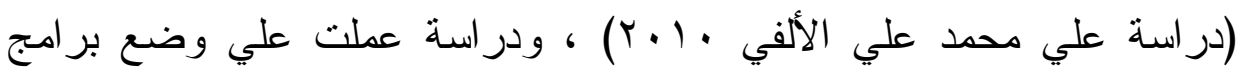
للتربية القيمية منل دراسة (Madhavi Mojmurdar 1998 )، أما الدراسة الحالية فتتناول دور القيم التربوية في مواجهة الإساءة والإهمال الموجهة

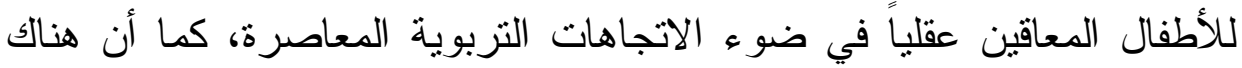
دراسات ركزت علي ماهية القيم الأخلاقية وطبيعتها ووسائل غرسها في نفوس الاهن

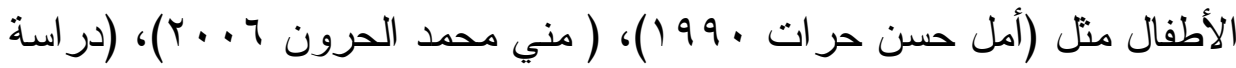

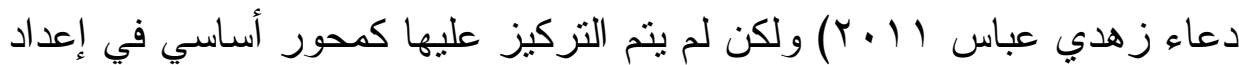

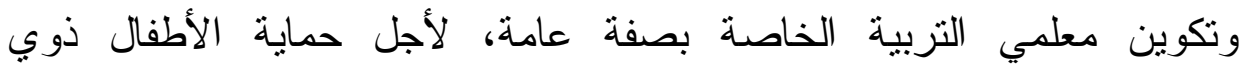
الاحتياجات التربوية الخاصة من الإساءة و الإهمال بصفة خاصة، وهو ما سوف

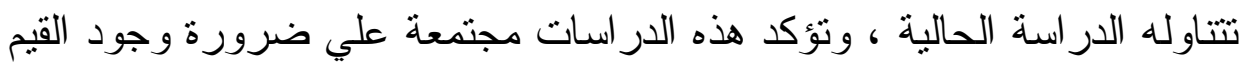

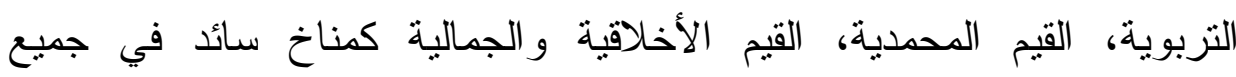

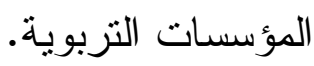

من خلال استعر اض بعض الدراسات التي تتاولت الإساءة و الإهمال تجاه

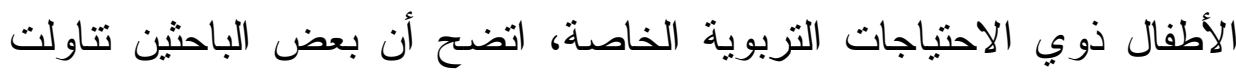

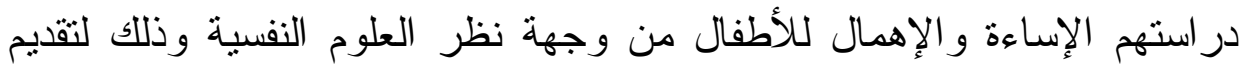

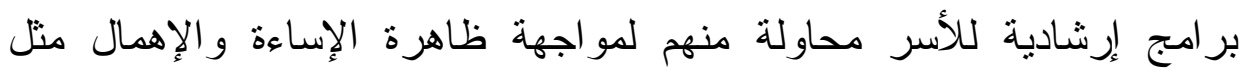




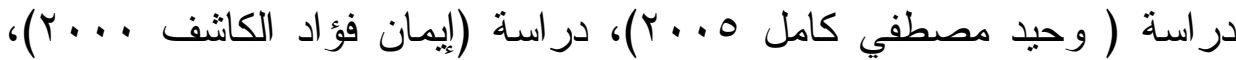

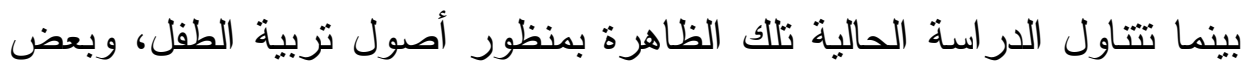

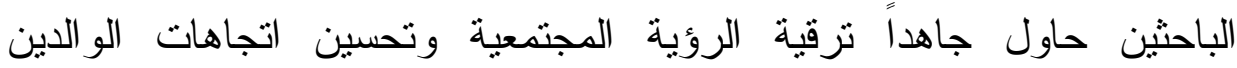

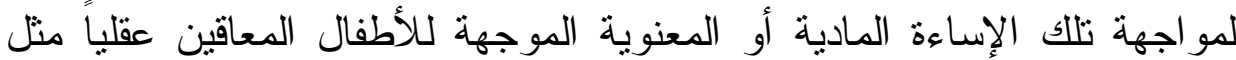

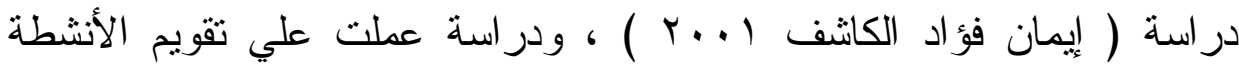
التربوية بمدارس التربية الفكرية بمحافظة الدقهلية منل دراسة ( نجلاء عبد

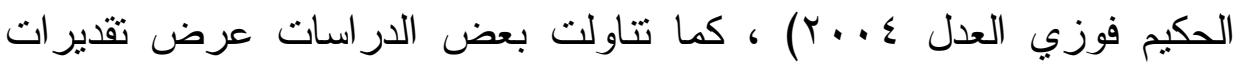
جديدة لمتوسط الأعباء الاقتصادية التي كلفتها إساءة معاملة الطفل مدي الحياة كدراسة (Xiangming Fang and others 2011)، ودراسات عرضت

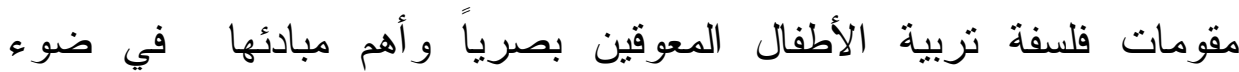

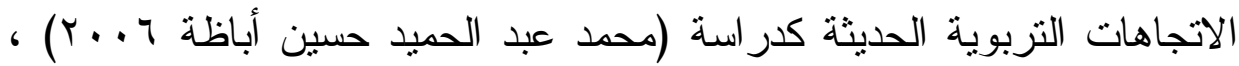
ودراسات هدفت إلي التعرف علي الآثار السلبية طويلة الددي لإساءة معاملة

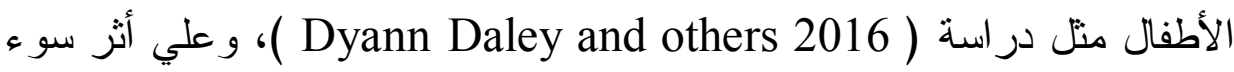
المعاملة العاطفية للأطفال و علاقتها بالصحة العقلية و الاضطر ابات الانفعالية مثل دلك در اسة (Tamara L. Taillieu and others 2016)، بينما تركز الدراسة الحالية علي القيم التربوية ودورها في مواجهة شتي أنثال الإساءة والإهمال الموجهة للأطفال المعاقين عقلياً في ضو ء الاتجاهات التزبوية المعاصرة. كما أن الدراسات العربية و الأجنبية مجتمعة أكدت على مدي جرم الإساءة و الإهمال في حق الأطفال بصفة عامة والأطفال ذوي الاحتياجات النربوية بصفة خاصة، لذلك تحاول الدراسة الحالية مواجهة الإساءة والإهمال قدر الإل

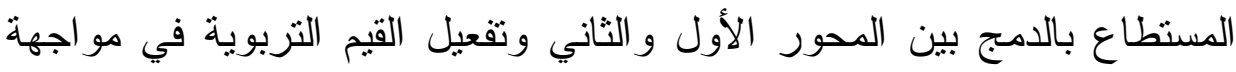

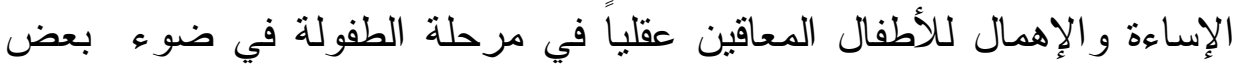
الاتجاهات التزبوية المعاصرة. 
كما لم تجد الباحثة - على حد علمها - دراسات تتاولت القيم التربوية في مواجهة الإساءة والإهمال تجاه الأطفال ذوي الاحتياجات التربوية الخاصة، فهنالك دراسات تتاولت القيم التزبوية في مراحل التعليم الثانوي و الابتدائي ومرحلة رياض الأطفال، دراسات تتاولت الإساءة و الإهمال الموجهة للأطفال اللذين يعانون من الإعاقات المختلفة، وبعض الدراسات التي تطرقت للقيم التزبوية في مواجهة الإساءة والإهمال كجزء منها ، ودراسات تتاولت القيم

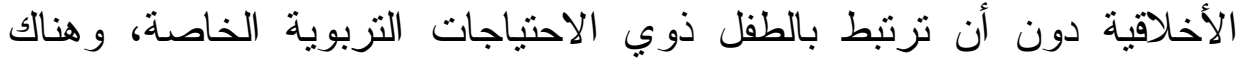
بعض الدر اسات تناولت متغيرين فقط هما الإساءة و الإهمال و التخلف العقلي متل

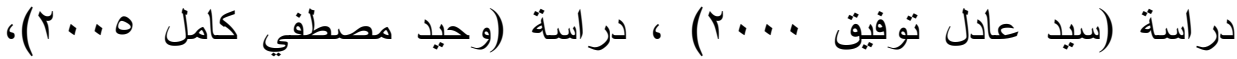
و أيضا دراسة هدفت إلي التعرف علي حالات الأطفال الذين يعانون من الإساءة

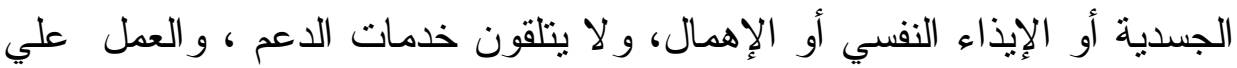
تقديم خدمات لجميع الآباء والأمهات لحسن رعاية الطفل مثل دراسة الطاء ،(Hiroyuki Horikawa , S. Pilar Suguimoto and others2016) بينما تحاول الدراسة الحالية تناول القيم التربوية ودورها في مواجهة الإساءة

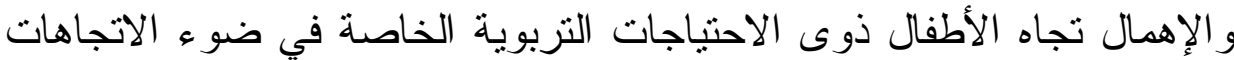

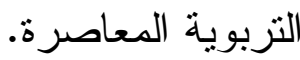

الإحساس بقضية البحث

"وحيث أن مجال الإعاقة في مرحلة الطفولة المبكرة قد نال اهتماما بالغاً

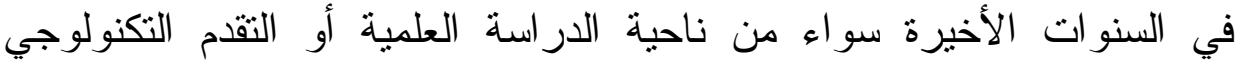
ويرجع الاهتمام من ناحية الاقتتاع المتز ايد في المجتمعات المختلفة بأن الأطفال

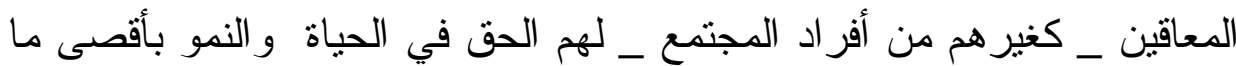
تمكنهم طاقتهم وقدر اتهم، ومن ناحية ثانية ، فإن اهتمام المجتمعات بأطفالنا

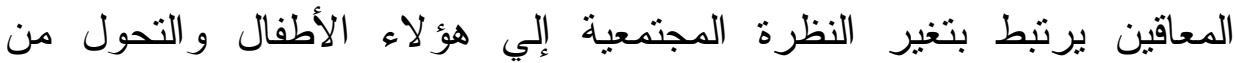


اعتبارهم عالة اقتصادية علي مجتمعاتهم إلي النظر إليهم كجزء من الثروة

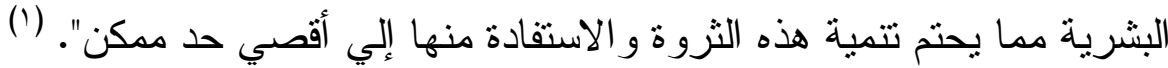

و هنالك العديد من الإحصائيات و المؤشر ات الدالة علي الاهتمــام النسـبي

بمجال التربية الخاصة في جمهورية مصر العربية ، لاسيما محافظتي القـاهرة و الدقهلية ؛ ولكن لانجزم بأن هذا الاهتمام كافي بالقدر الذي يليق برعاية الأطفال

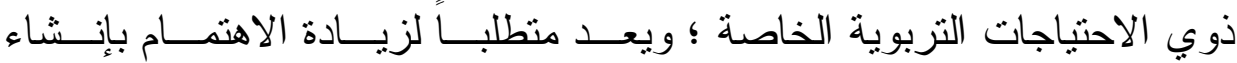

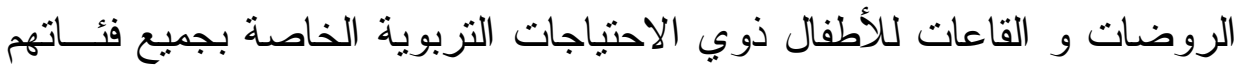

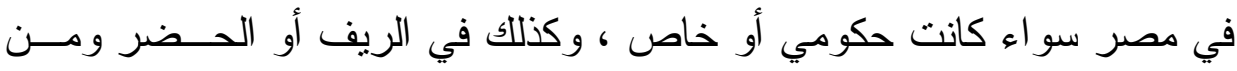

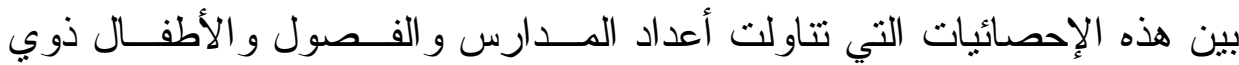
الاحتياجات التزبوية الخاصة كما يلي:

جدول (1)

إحصائيات ومؤشرات مدارس وفصول مرحلة ما قبل التعليم الابتدائي

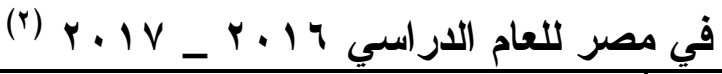

\begin{tabular}{|c|c|c|c|c|}
\hline \multicolumn{4}{|c|}{ مرحلة ما قبل المدرسة } & \\
\hline ريف & حضر & خاص & حكومي & \\
\hline$T$ T 11 & $\{\Lambda . r$ & rr9o & 1900 & مدارس - مد \\
\hline lovar & 10V9V & $1 . \leq 4 V$ & אזד או & فصول \\
\hline
\end{tabular}

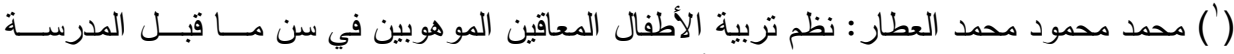

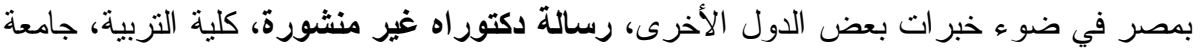

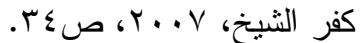

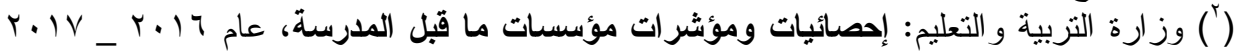

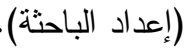


جدول (r)

إحصائيات ومؤشرات إجمالي التربية الخاصة في مصر

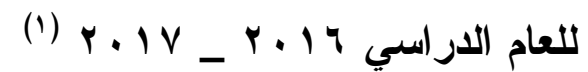

\begin{tabular}{|c|c|c|c|c|}
\hline \multicolumn{4}{|c|}{ جملة التربية الخاصة } & \\
\hline ريف & حضر & خاص & حكومي - (2 - مي & Jo \\
\hline rir & 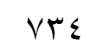 & iv & १५१ & مد مدارس \\
\hline N14 & TrT. & Av & $\{019$ & 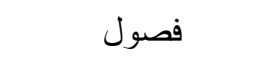 \\
\hline
\end{tabular}

جدول (r)

إجمالي عدد المدارس للتربية الخاصة بمحافظة القاهرة و الدقهلية. (ץ)

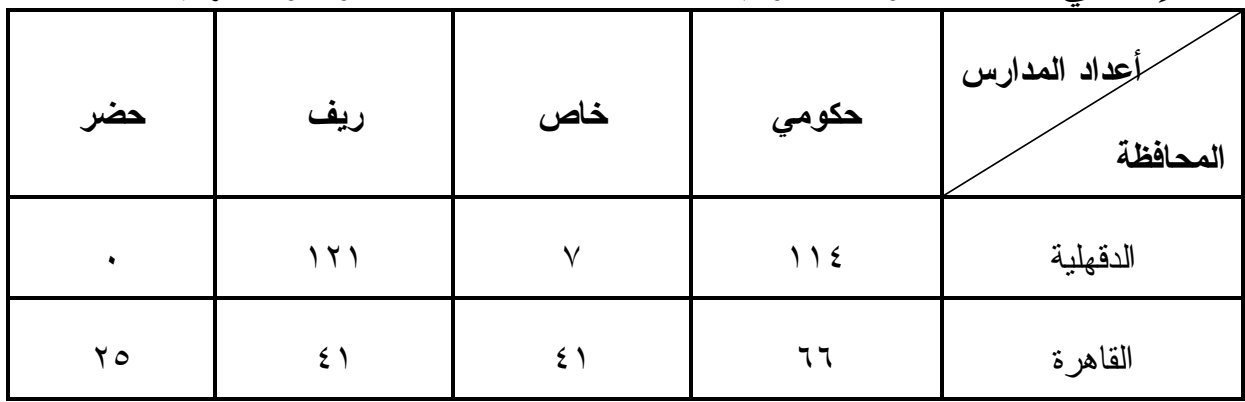

وشهدت متابعة الإحصائيات بأعداد المدارس المخصصة لمرحلة ما قبـلـل

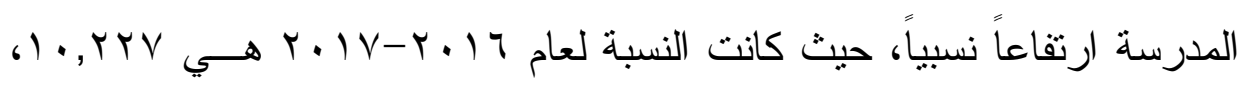

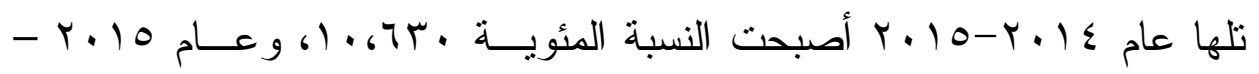

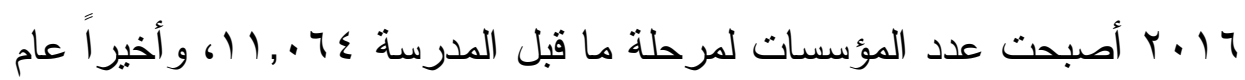

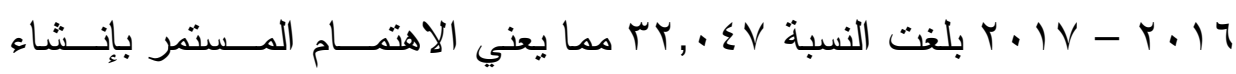

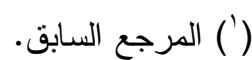

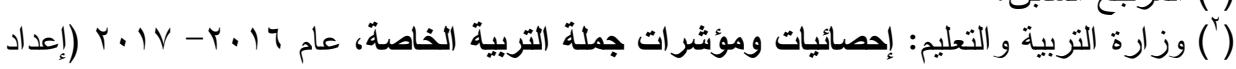
الباحثة).

العدد الثالث : يناير r.lV

vq

المجلد الثالث 
مؤسسات تربوية للأطفال في سن ما قبل الددرسة حتى وإن كان هذا العدد غير كاف. (')

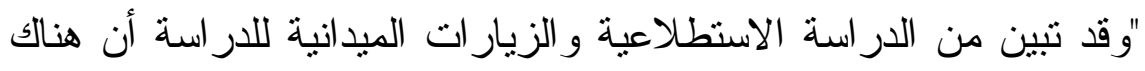

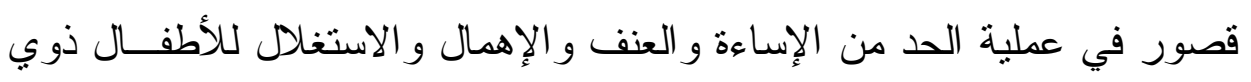

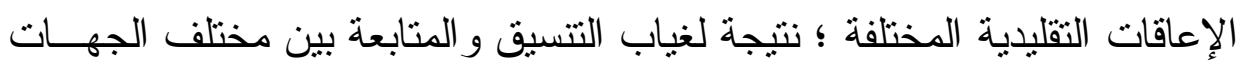

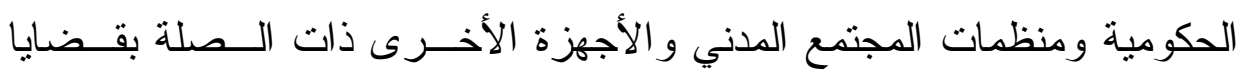

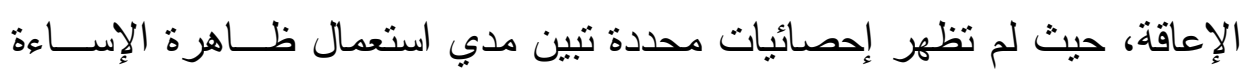

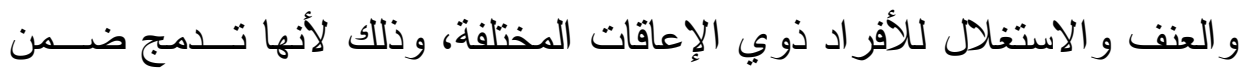

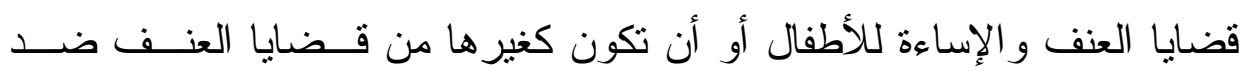

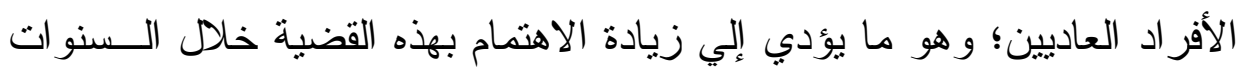

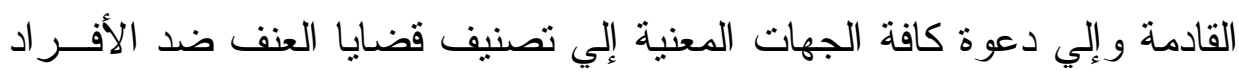

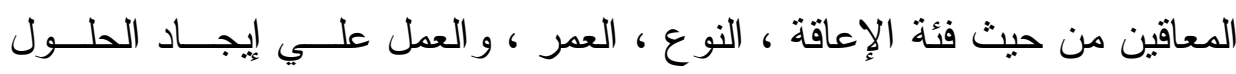

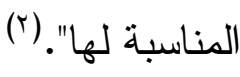

كما أن هناك تقسيمات متعددة للإعاقة من وجهة نظر العديد من العلمــاء

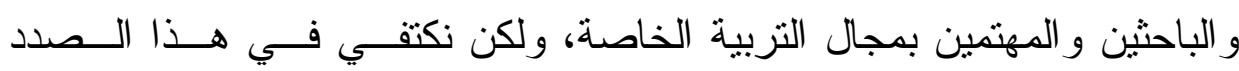

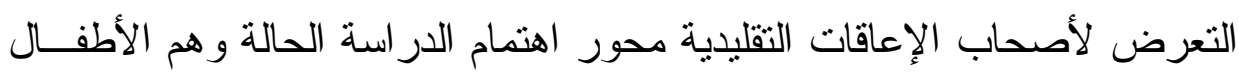

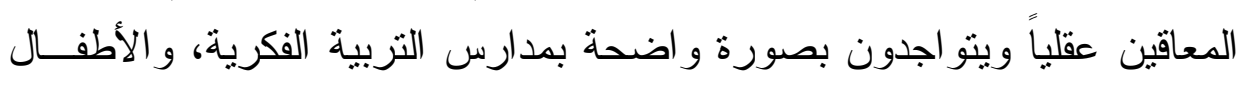

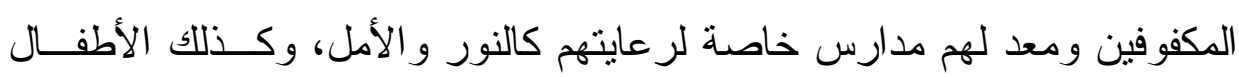
المعاقين سمعياً الملتحقين بمدارس الصم و والبكم.

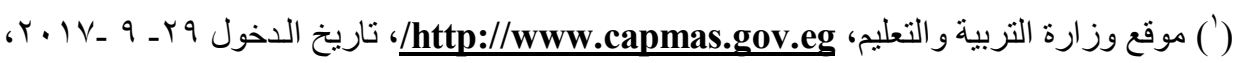
س־7 (1) (Y) رشاد عبد العزيز موسي: إرشاد الطفل المعاق لمواجهة العنف، دار الوفاء للطباعــة و النـشر ،

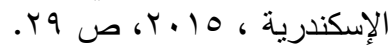




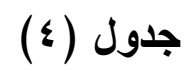

إجمالي عدد الأطفال المعاقين ومؤسسات رعايتهج

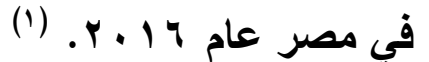

\begin{tabular}{|c|c|c|c|}
\hline الإعاقة العقلية & الصم والبكم & المكفوفين & نوع الإعاقة \\
\hline r... & «10 & T. & إجمالي عدد الأطفال في مصر \\
\hline$\sum \uparrow$ & & $\Lambda \wedge$ & إجمالي عدد الددارس في مصر \\
\hline
\end{tabular}

ويتضح من الجدول السابق ارتفاع نسبة الأطفال المعاقين عقليـاً، وعـدـد مؤسسات رعايتهم الخاصة عن أصحاب الإعاقات النقليدية الأخرى كــالمكفوفين

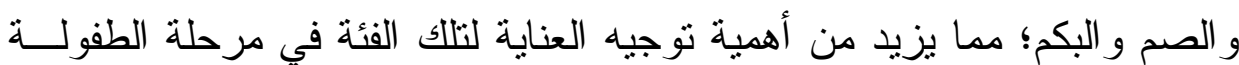

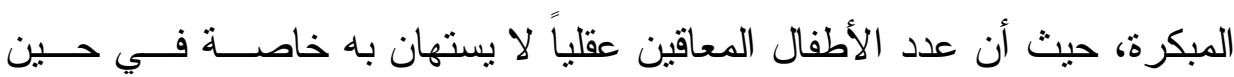

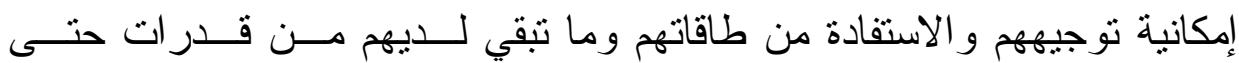

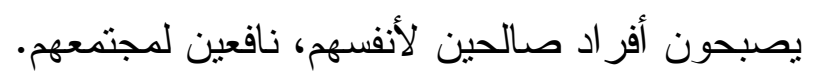

وجاءت أهمية نوظيف القيم التربوية لدي معلمي التربية الخاصة و وأولياء

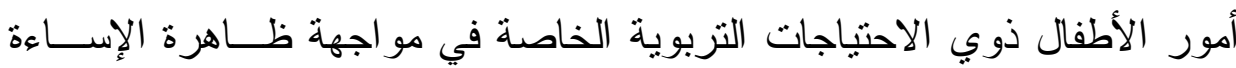

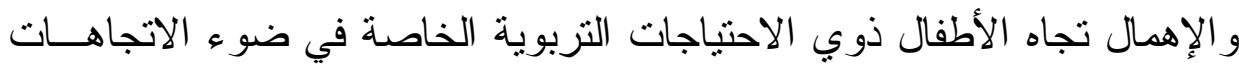
التزبوية المعاصرة ؛ من أعداد الأطفال ذوي الاحتياجات التربوية الخاصة سواء الأ كانو ا بالحضر أو الريف أو ملتحقين بمؤسسات رعاية حكومية أو خاصة وكذلك الك الكان أيضاً غير الملتحقين بمؤسسات رعاية تربوية فهي فئة ليست بقليلة وتحتاج إلـي رئي

(') الجهاز المركزي للتعبئة العامة و الإحصاء: إحصائيات إجمالي عـدد الأطفــال المعـاقين، عـام $. r .17-r .10$ 
الرعاية التربوية الاقيقة و المتخصصة من قبل معلمي التربية الخاصـــة وأوليــــاء أمور الأطفال ذوي الاحتياجات التربوية الخاصة.

$$
\text { جدول (0) }
$$

أعداد الأطفال ذوي الاحتياجات التربوية الخاصة

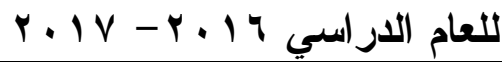

\begin{tabular}{|c|c|c|c|c|c|c|c|c|c|c|}
\hline \multicolumn{10}{|c|}{ جملة الأطفال ( التلاميذ) ذوي الاحتياجات التربوية الخاصة } & أكلاد الأطفال \\
\hline \multicolumn{2}{|c|}{ 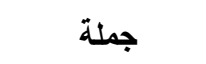 } & \multicolumn{2}{|c|}{ ريف } & \multicolumn{2}{|c|}{ 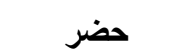 } & \multicolumn{2}{|c|}{ خاص } & \multicolumn{2}{|c|}{ حكومي } & \\
\hline أناث & ذكور & إناث & ذكور & إناث & ذكور & إناث & ذكور & إناث & ذكور & الجنس \\
\hline rVTI & $1 \ldots 1$ & Y1T & $\varepsilon \cdot r$ & VQY & 1ro. & . & . & $1 \cdots 1$ & IVor & الدقهلية \\
\hline
\end{tabular}

من هنا يتضح أهية الدراسة في مجال القيم التربوية ودور ها في مو اجهة

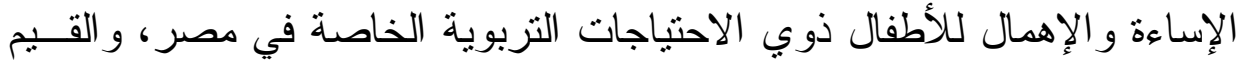

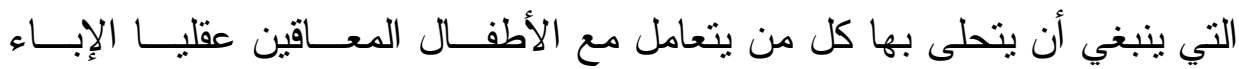

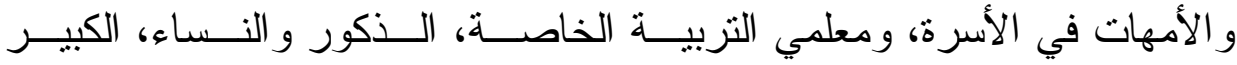
و الصغير في المجتمع؛ لكي نتخلص المفاهيم و الأفكار المغلوطة عــن الأطفــال ذوي الاحتياجات التربوية الخاصة، وتحد قدر الإمكان من الإســاءة و الإهـــال الموجه للأطفال المعاقين عقلياً.

\section{قضية البحث}

علي الرغم من الجهود التي تبذلها الجهات الرسمية و الأهلية فـــي مجــال

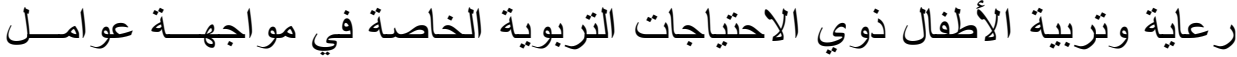

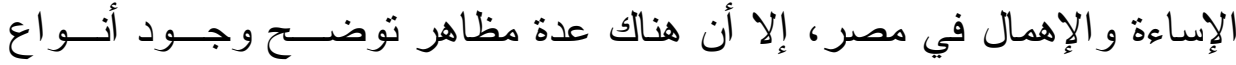


الإسـاءة و الإهمال التي يتعرض لها هؤلاء الأطفــال كمـــا أظهرتهـــا الدراســـة

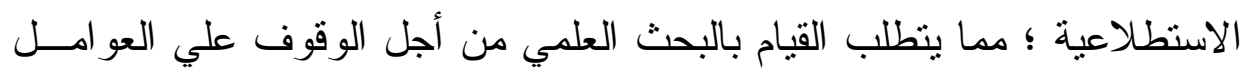

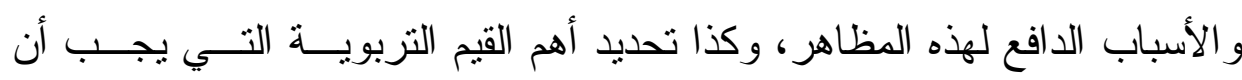

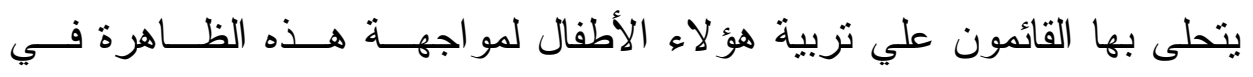

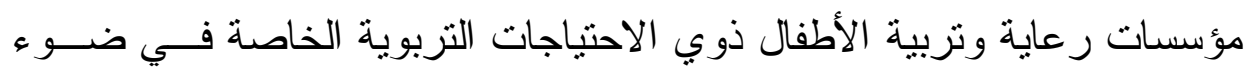

$$
\text { بعض الاتجاهات التزبوية المعاصرة. }
$$

وتطرح قضية الار اسة السؤال الرئيس التالي :

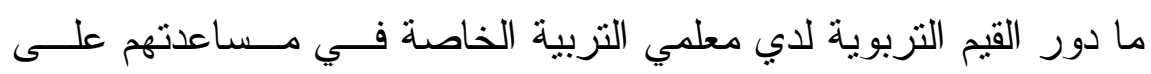

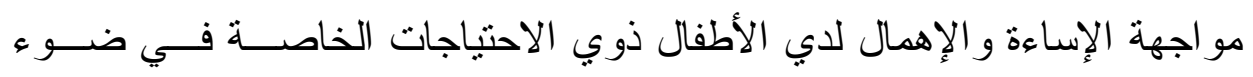
بعض الاتجاهات التربوية المعاصرة؟

و يتفرع من هذا التساؤل الأسئلة الفرعية الآتية:

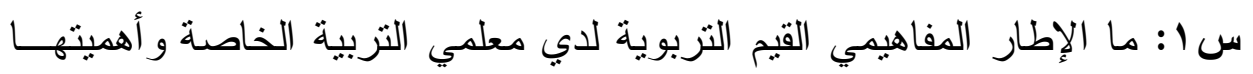

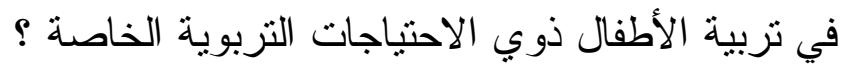

س r: ما طبيعة الإساءة و الإهمال التي ينترض لها الأطفــال ذوي الاحتياجـات

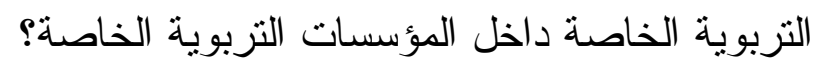

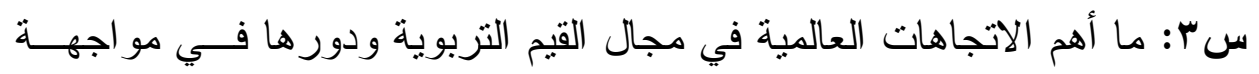

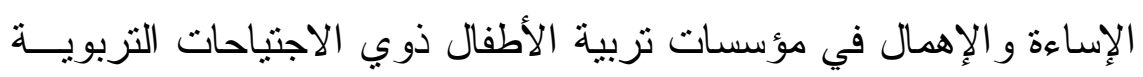

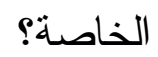

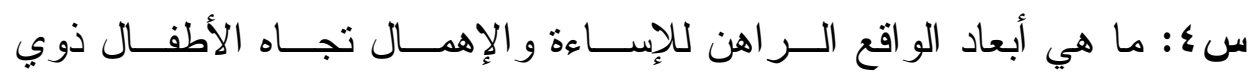

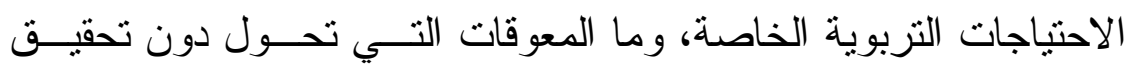

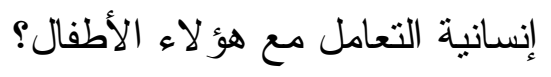


س ه: ما جو انب الرؤية التربوية المقترحة في مجال تفعيل دور القـيم التربويــة

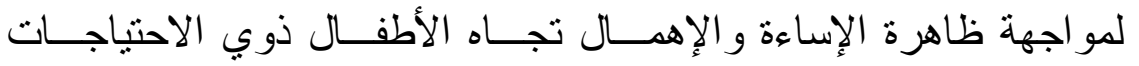

التزبوية الخاصة؟

\section{أهداف البحث}

تتعدد أهداف الدراسة الحالية لتتمل عدد من الأهداف النظرية و الأهداف التطبيقية في مجال القيم التربوية ودور ها في مواجهة ظاهرة الإساءة و الإهـــال تجاه الأطفال ذوي الاحتياجات التربوية الخاصة وهي كما يلي.

الأهداف افت التظرية

1- التعرف علي أهم القيم التربوية التي يجب نو افرها لدي معلمــي التربيـــة

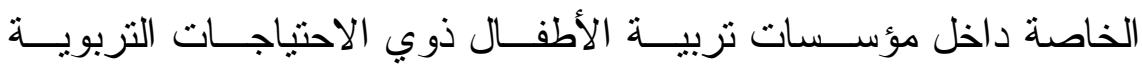

الخاصة.

r- تحديد مظاهر الإســاءة والإهمـــال التــي يتعــرض لهـــا الأطفــال ذوي

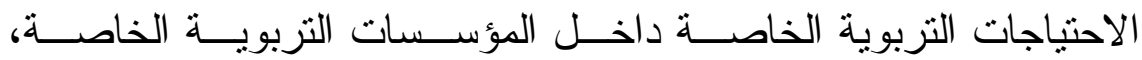

و الأسرة، و العو امل و الأسباب الدافعة لها.

ب- التعرف على أهم الاتجاهات التربوية المعاصرة في مجال القيم التربويـــة

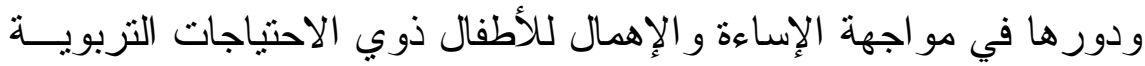

الخاصة لاسيما (المعاقين عقلياً). 


\section{الأهداف التطبيقية}

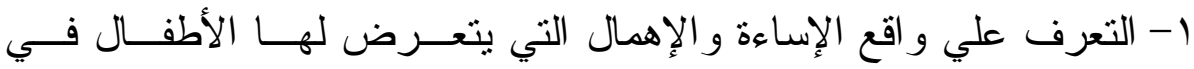

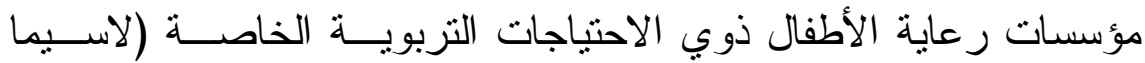

مؤسسات التزبية الفكرية).

r- - طرح رؤية تربوية مقترحة لتفعيل القيم التربوية لدي معلمـي التربيــة

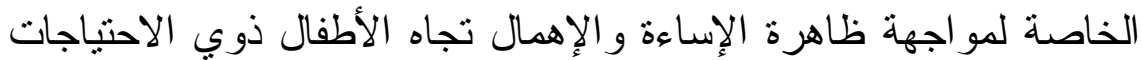

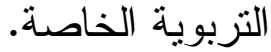

أهمية البحث

تأتي أهمية البحث الحالي من خلا النقاط التالية :

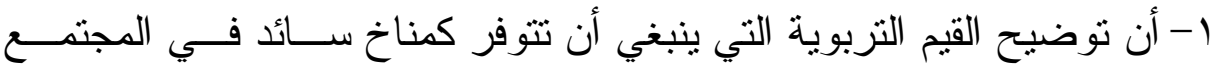

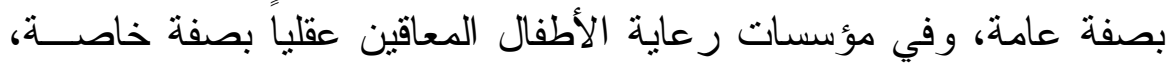

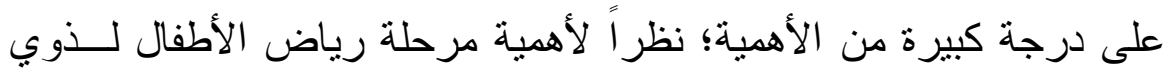

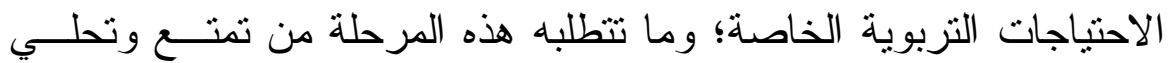

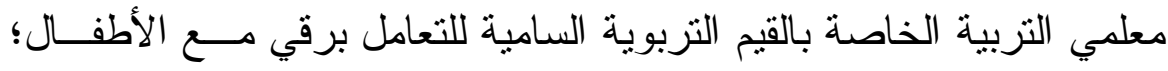

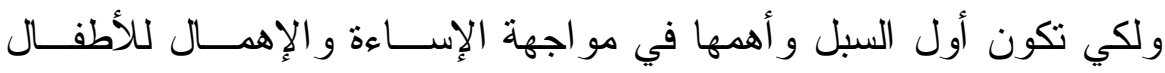

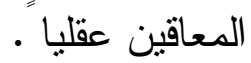

ץ-شيوع ظاهرة الإساءة و الإهمال لدي الأطفال ذوي الاحتياجـات التزبويـــة

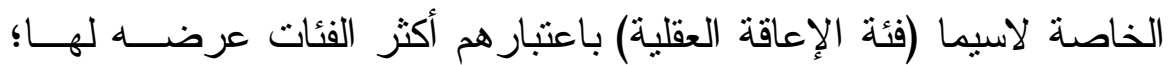

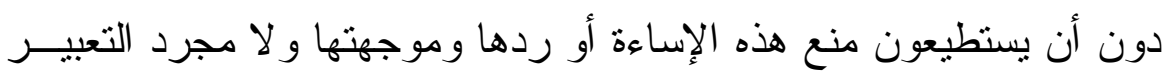
عنها، مما يشكل خطورة كبيرة على مستقبل حياة هؤ لاء الأطفال. 
ץ- أن ظاهرة الأطفال ذوى الاحتياجات التربوية الخاصــة لا تخطئهـــا عـين المر اقب خاصة أن التخلف العقلي يمثل (10 1 \% من حجم الإعاقات بشكل

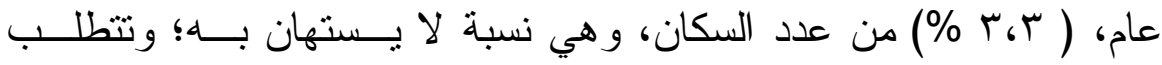

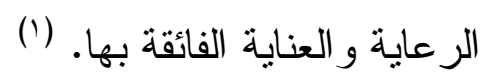

ع- ندرة البحث العلمي- في حدود علم الباحثة - في مجال ربط القيم التربويــة

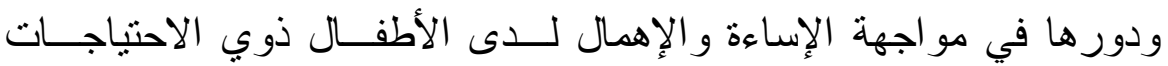

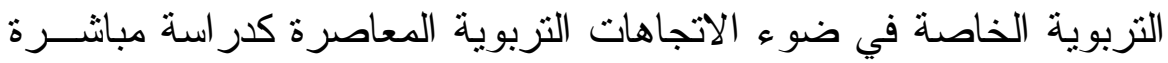
مرتبطة المتغير ات.

ه- أن الوقوف على الاتجاهات التربوية المعاصرة في مجال القـيم التربويـــة

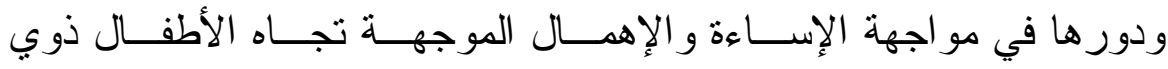

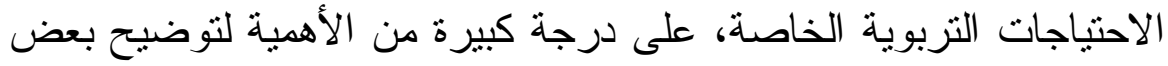

$$
\begin{aligned}
& \text { المعايير التي تخدم دوضوع الدر اسة. } \\
& \text { ؟-تعدد المستقيدين من هذه الدر اسة وهم: }
\end{aligned}
$$

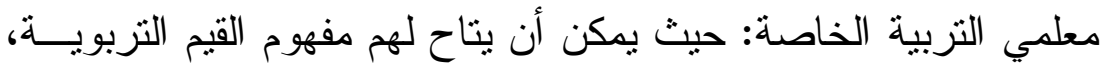

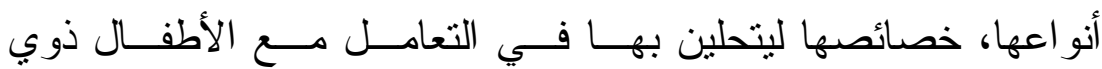

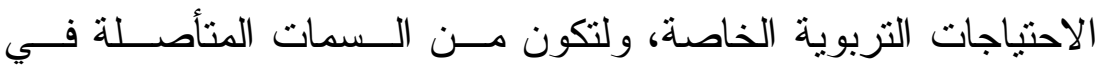
شخصيات معلمي التربية الخاصة.

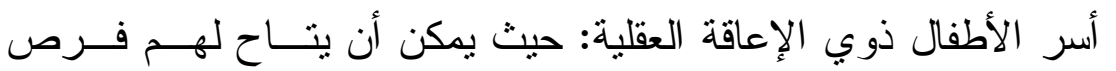

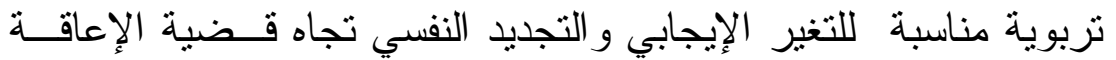

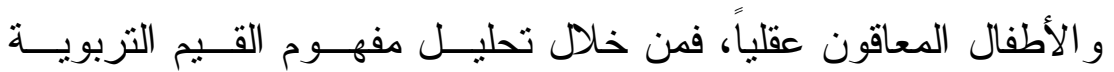

(') إيمان فؤاد الكاثف: مرجع سابق ، ص 11 ا. 
ودور ها في مو اجهة الإساءة و الإهمال، و الإعاقة العقلية ومعرفة الحكمة

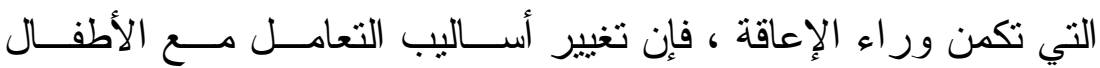

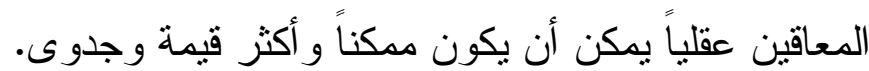

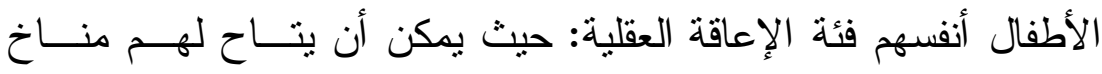
تربوي أسرى ومجتمعي يقوم على الإيمان بالقضاء و القدر، وتأثثير اتــــ الإيمانية على كيفية التعامل مع هؤلاء الأطفال كأفر اد إنسانين يجب أن إن باءن

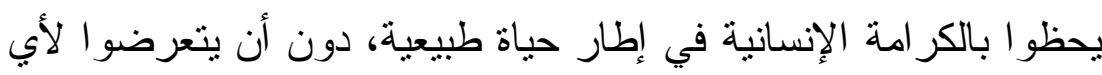
أثنكال الإساءة و العنف و الإهمال ('). المجتمع : حيث بمكن أن تساعد الدر اسة الحالية فـي تغيــر النظـــرة المجتمعية تجاه الإعاقة، الأطفال المعاقين عقليا، وخاصة في تو افر القيم التربوية و الأخلاقية السامية لدي الو الدين ومعلمي التربية الخاصة.

حدود البحث:

يشكل البحث الحالي لنفسه حدوداً تبرز معالمه ويلتزم بالعمل في إطارها وهي: ( ) الحدود الموضوعية(الأكاديمية) حيث تتحدد محاور الدر اسة فيما يلي:

$$
\text { • القيم التربوية لاي معلمي التربية الخاصة. }
$$

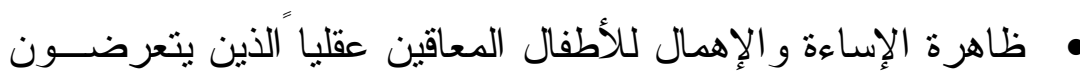

$$
\text { للإسـاءة أكثر من ذوي الإعاقات التقليدية الأخرى. }
$$

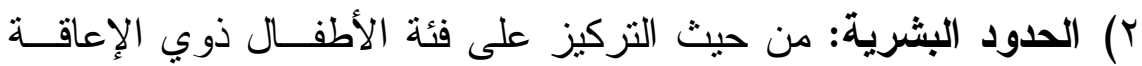
العقلية في مرحلة الطفولة (مبكرة، متوسطة، منأخرة)، أوليــاء أمسـور

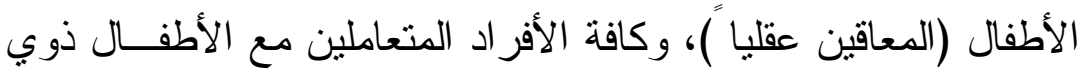

(') جابر محمود طلبه: مرجع سابق ، صوه. 
الإعاقة العقلية داخل مؤسسات رعايتهم الخاصة من (معلمي التربيــة الخاصة، أولياء أمور الأطفال ذوي الاحتياجات التزبوية الخاصة).

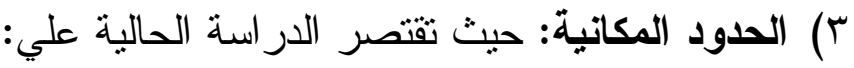

بعض مدارس التربية الفكرية الحكومية و الأهلية في محافظة الدقهلية. بعض مدارس النور للمكفوفين ، مدارس الـــم و الــبكم الحكوميــة

بمحافظة الدقهلية.

\section{منهج البحث}

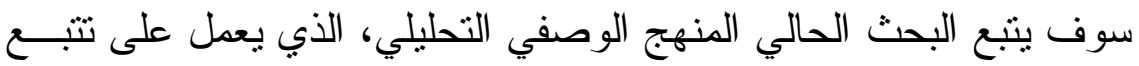

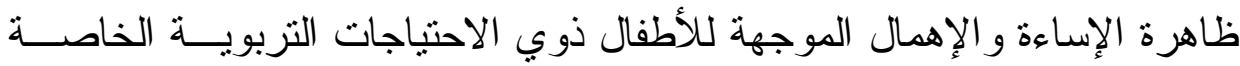

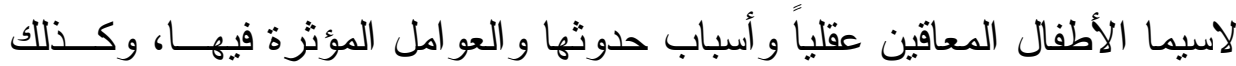

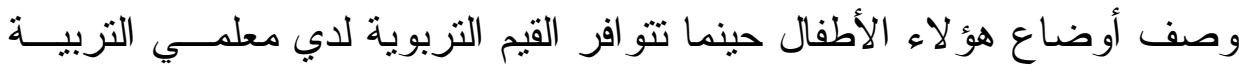

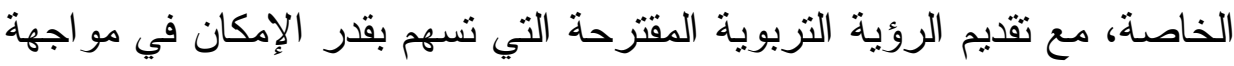

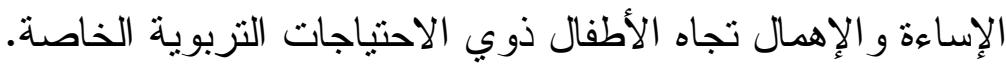
عينة البحث سوف يقتصر البحث الحالي على الآي:

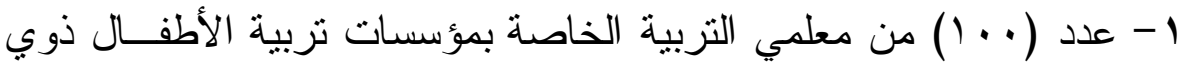
الاحتياجات التزبوية الخاصة بمحافظة الدقهلية. r- عدد ( . (1) من أباء و أمهات الأطفال الملتحقين بمؤسسات تربية الأطفال ذوي الاحتياجات التربوية الخاصة في محافظة الدقهلية. أدوات البحث سوف يستخدم البحث الأدوات التالية: - استبانة موجهة لمعلمي التربية الخاصة: بهذف الوقوف على و اقع القيم التزبوية وكيفية نوظيفها في مواجهة الإساءة والإهمال للأطفال ذوي الاحتياجات التربوية الخاصة. (إعداد الباحثة) 
- استبانة موجهة لأولياء أمور الأطفال ذوي الاحتياجات التربوية الخاصة:

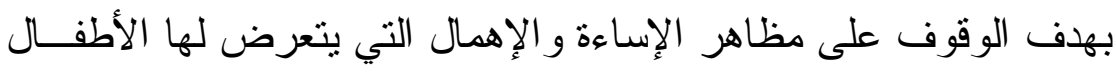
ذوي الاحتياجات التزبوية الخاصة. (إعداد الباحثة)

$$
\text { سوف تتبع الباحثة الخطوات التيات البية: }
$$

1- الوقوف على الأدب التربوي في مجال القيم التزبوية ودور ها في مو اجهة قضية الإساءة و الإهمال تجاه الأطفال ذوي الاحتياجات التزبوية الخاصة.

$$
\text { r- تكوين الإطار النظري و الدراسات السابقة. }
$$

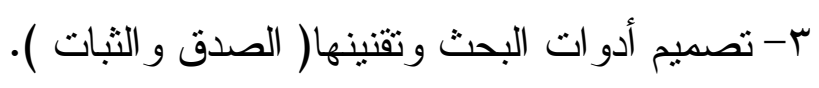

$$
\text { ع - القيام بالار اسة الميدانية. }
$$

0- تحليل نتائج الدر اسة الميدانية وتفسير ها.

$$
\text { 1- عرض الرؤية التربوية المقترحة. }
$$

نتائج البحث

توصل البحث الحالي إلي بعض النتائج الهامة في مجال القـيم التربويـــة

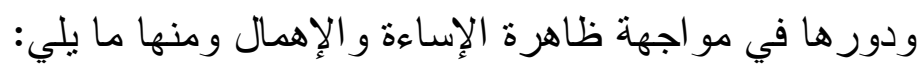

1. وجود مظاهر متعددة للإساءة للأطفال ذوي الاحتياجات التربوية الخاصة داخل مؤسسات رعايتهم من قبل معلمي التربية الخاصة وكافة القائمين علي تربيتهم وتتميتهم داخل تلك المؤسسات التربوية الخاصة. r. ضعف مستوي القيم التربوية لدي بعض معلمي التربية الخاصة وأولياء أمور الأطفال ذوي الاحتياجات التربوية الخاصة. r. ضعف المستوي التعليمي و الثقافي والإقتصادي لبعض أسر الأطفال ذوي الاحتباجات التربوية الخاصة. 
ع. رفض المؤسسات التربوية المختلفة لبعض الاتجاهات العالمية المعاصرة

كالدمج و إكتشاف المواهب من الأطفال ذوي الاحتياجات التربوية

الخاصة.

0. قصور إلمام بعض أولياء أمور الأطفال ذوي الاحنياجات التربوية الخاصة بالأساليب التزبوية السوية اللازمة لرعاية أبنائهم و المساهمة في

$$
\text { حمايتهم من الإساءة و الإهمال. }
$$

7. قلة إلمام معلمي التزبية الخاصة بالإتجاهات التزبوية الحديثة ومستحدثات

العلم وتجارب وخبر ات بعض الدول المتقدمة في مجال التربية الخاصة.

V. قصور الاهتمام بمجال التزبية الخاصة من اعداد معلمي التربية الخاصة ، و إنشاء مؤسسات تربوية خاصة لكل فئة من فئات الإعاقة، وكذلك ندرة الندو ات و المؤتمر ات الدورية في مجال التربية الخاصة.

الروئية التربوية المقترحة

قامت الباحثة بوضع روئة تربوية مقترحة من أجل تفعيل القيم التربوية وتفعيل دور ها في مو اجهة الإساءة و الإهمال للأطفال ذوي الاحتياجات التربوية الخاصة في ضوء بعض الاتجاهات التربوية المعاصرة. وتثمل الروئة التريوية المقترحة ما يلي: ا ـ أهداف الرؤية التربوية المقترحة

•تمية القيم التربوية لدى معلمي التربية الخاصة و أولياء الأمور من خلال الإعداد الأكاديمي و الدورات التدريبية ومساعدتهم علي التحلي بها داخل الأسر و المؤسسات التزبوية الخاصة. 
• التغلب علي مظاهر الاساءة والاهمال التي يتعرض لها الأطفال داخل

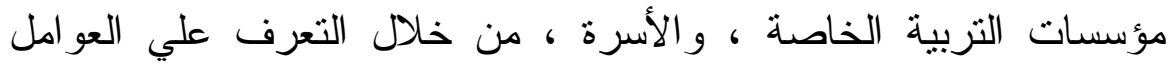
و الاسباب الدافعة لها ومو اجهتها.

r. الأسس التي تقوم عليها الروئية التربوية المقترحة

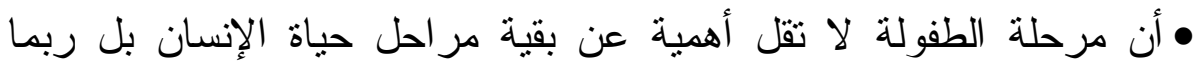
تكون أهم مرحلة لأن فيها نتشكل شخصية الطفل بما يؤثر سلباً أو إيجاباً على سلوكه فى حاضره ومستقبله. • أن مرحلة الطفولة أثند أهمية في حياة الأطفال ذوي الاحتياجات التربوية

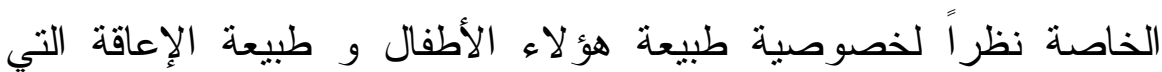

$$
\text { بعانون منها. }
$$

r. مرتكزات الروئة التربوية المقترحة

• إذا كانت ظاهرة الإساءة والإهمال للأطفال العاديين مُضرة، فالإساءة

للأطفال ذوي الإحتياجات التربوية الخاصة هي أكثر مضرة.

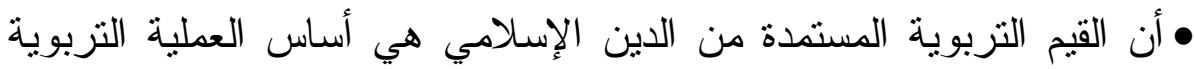
خاصة إذا كانت داخل المؤسسات التربوية الخاصة.

$$
\text { ؛ . جوانب الروئة التربوية المقترحة }
$$

$$
\text { • • • الجانب الجانب القبمي }
$$

هـ متطلبات تحقيق الروية التربوية المقترحة.

• (منطلبات فكرية ومعرفية 


$$
\text { • • منطلبات إدارية وتتظيمية }
$$

7. آليات تطبيق الرؤية التربوية المقترحة

• ضرورة تقديم الدور ات التدريبية المتخصصة لمعلمـي التربيــة الخاصـــة

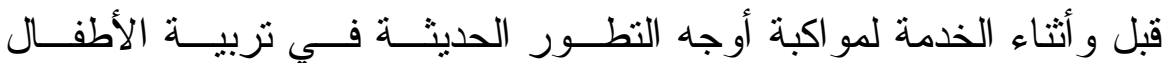

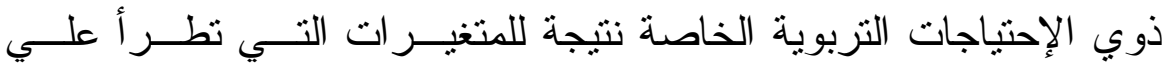

$$
\text { المجتمع. }
$$

• عقد ندو ات ومؤتمر ات دورية ذات طابع عالمي لتوحيد حقوق الأطفال ذوي الإحتياجات التربوية الخاصة، لإشعار هؤلاء الأطفال بوجود من يهتم بهر فعلا ويحرص علي رعايتهم وحمايتهم من الإساءة و الإهمال.

$$
\text { V. معوقات تطبيق الرؤية التربوية المقترحة }
$$

• الو اقع السائد في مصر المهمش لفئة الاطفال ذوي الاحتياجــات التربويـــة الخاصة، ورغم الاهتمامات الحالية بمجال التربية الخاصة الإ أنها مازلــت غير كافية لتحسين أحو ال تلك الفئة وتزقية معيشتهم.

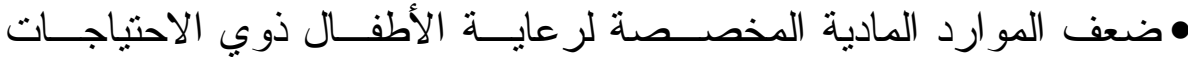
التزبوية الخاصة، ويرجع السبب الرئيسي في ذلك ضعف الموارد الماليـــة المنفقة على التعليم في مصر بوجه عام. ^. وسائل تقيبم الروئية التربوية المقترحة • متابعة أساتذة الجامعة المتخصصين في تربية الطفل مجال رعاية وتتمية الأطفال ذوي الاحتياجات التزبوية الخاصة من معلمين - وشكل المؤسسة - و البر امج التي تقدم بها. 
• القيام بزيار ات مفاجئة دائمة للمؤسسات التربوية الخاصة لاسيما الحكومية

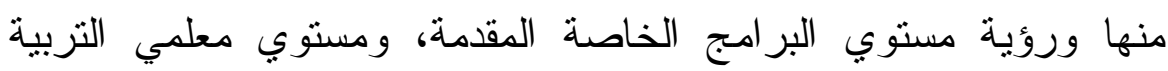

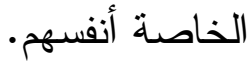

9 ـ. التغذية الراجعة وسائل تقويم الروئية التربوية المقترحة

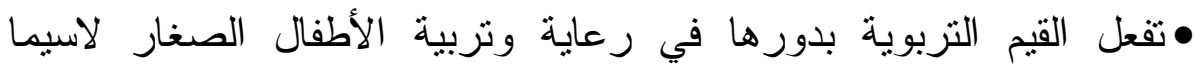
الأطفال ذوي الاحتياجات التربوية الخاصة.

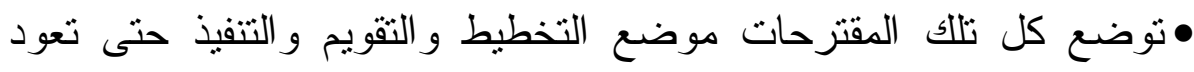
بالنفع على الأطفال ذوي الاحتياجات التزبوية الخاصة.

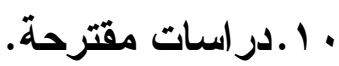
• القيم التزبوية ودور ها في مو اجهة الإساءة والإهمال من قبل صغار الباحثنين إلى كبار العلماء. • القيم الثربوية ودورها في مو اجهة الإساءة و الإهمال للأطفال المو هوبين في الكي ضو بع بعض الاتجاهات الثربوية المعاصرة. 


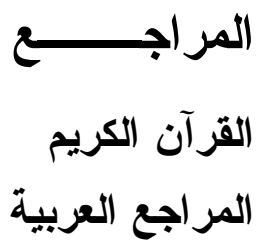

1- إيمان عبد اله شرف : التربية الأخلاقية للطفل، الطبعة الثانية، مكتبة عالم

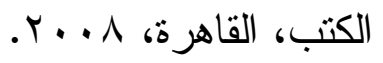

Y- إيمان فؤ اد الكاثثف: الإعاقة العقلية بين الإهمال و التوجيه، مكتبة الفجالـــة،

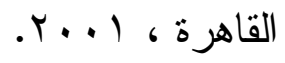

ץ-جابر محمود طلبة: إنسانية تربية الطفـل، مكتبــة جريــر، المنــصورة ،

$$
. r . . V
$$

ع- حسن السيد شحاتة: أدب الطفل العربي در اسات وبحوث، الطبعــة الثانيــة،

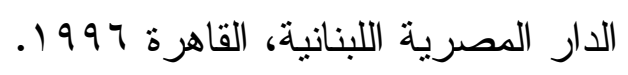

0- رشاد عبد العزيز موسي: إرشاد الطفل المعاق لمواجهة العنف، دار الوفاء

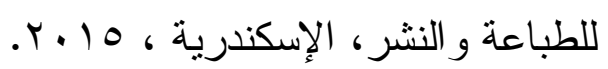

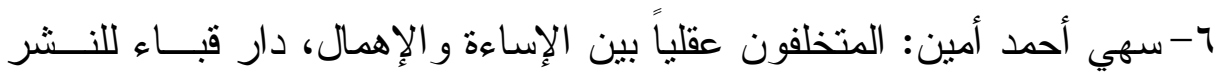

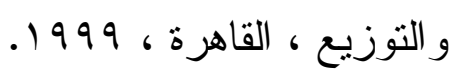

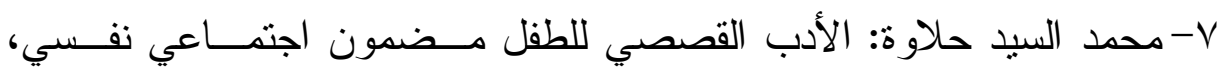

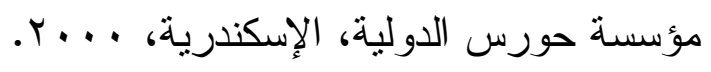

1- محمد محمود محمد العطار : نظم تربية الأطفال المعاقين الموهوبين في سن

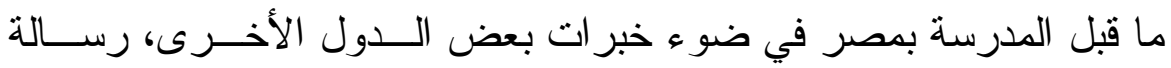

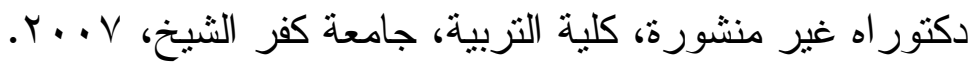

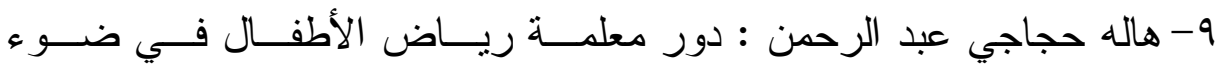

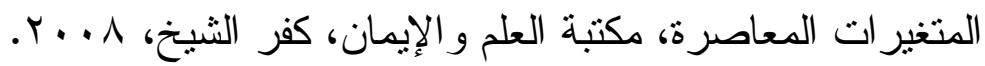




\section{مواقع الانترنت}

10- http://www.capmas.gov.eg/

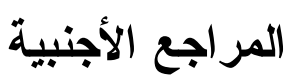

11- Commonwealth of Australian, department of education, science and training, National Frame Work for Values Education in Australian Schools 2005.

12- Xiangming Fang, Derek S. Brown, and others: The economic burden of child maltreatment in the United States and implications for preventio، vol(36)، Child Abuse \& Neglect، USA، 2012.

13- Dyann Daley, Christian Pedigo and others: Risk terrain modeling predicts child maltreatment, Child Abuse \& Neglect، Fort Worth، USA، 2016.

14- Tamara L. Taillieu and others: Childhood emotional maltreatment and mental disorders: Results from a nationally representative adult sample from the United States ،Child Abuse \& Neglect، vol(59)،USA، 2016.

15- Hiroyuki Horikawa, S. Pilar Suguimoto and others: Development of a prediction model for child maltreatment recurrence in Japan: A historical cohort study using data from a Child Guidance Center ،Child Abuse \& Neglect ‘vol(59)،Japan‘2016. 